\title{
Visible-Light Enhanced Catalytic Wet Peroxide Oxidation of Natural Organic Matter in the Presence of A1/Fe-Pillared Clay
}

\author{
Cristian S. Portilla-Delgado ${ }^{1}$, Ana M. García-Mora ${ }^{1}$, Frederic Dappozze ${ }^{2}$, Chantal Guillard ${ }^{2}$ and \\ Luis A. Galeano 1,*(D) \\ 1 Grupo de Investigación en Materiales Funcionales y Catálisis (GIMFC), Departamento de Química, \\ Cra. 50 Campus Torobajo, Universidad de Nariño, Calle 18, 520002 Pasto, Colombia; \\ sebastianporti@udenar.edu.co (C.S.P.-D.); anamariagarcia@udenar.edu.co (A.M.G.-M.) \\ 2 Institute of Researches on Catalysis and Environment of Lyon (IRCELYON), Université Claude Bernard \\ Lyon 1, 2 Avenue Albert Einstein, Villeurbanne, F-69626 Lyon, France; \\ frederic.dappozze@ircelyon.univ-lyon1.fr (F.D.); chantal.guillard@ircelyon.univ-lyon1.fr (C.G.) \\ * Correspondence: alejandrogaleano@udenar.edu.co; Tel.: +57-3184079325
}

\section{check for} updates

Citation: Portilla-Delgado, C.S.; García-Mora, A.M.; Dappozze, F.; Guillard, C.; Galeano, L.A.

Visible-Light Enhanced Catalytic Wet Peroxide Oxidation of Natural Organic Matter in the Presence of $\mathrm{Al} /$ Fe-Pillared Clay. Catalysts 2021 11, 637. https://doi.org/10.3390/ catal11050637

Academic Editor: Fernando J. Beltrán Novillo

Received: 28 April 2021

Accepted: 14 May 2021

Published: 16 May 2021

Publisher's Note: MDPI stays neutral with regard to jurisdictional claims in published maps and institutional affiliations.

Copyright: (c) 2021 by the authors. Licensee MDPI, Basel, Switzerland. This article is an open access article distributed under the terms and conditions of the Creative Commons Attribution (CC BY) license (https:// creativecommons.org/licenses/by/ $4.0 /)$.

\begin{abstract}
An $\mathrm{Al} / \mathrm{Fe}$-pillared clay catalyst (Al/Fe-PILC) prepared from low cost technical-grade reagents has been investigated in the photocatalytic Wet Peroxide Oxidation (photo-CWPO) of dissolved Natural Organic Matter (NOM) under circumneutral pH. The successful pillaring of the layered clay material was confirmed by X-ray diffraction (XRD), $\mathrm{N}_{2}$ adsorption at $-196{ }^{\circ} \mathrm{C}$, cation exchange capacity (CEC) and simultaneous thermal analysis (TGA/DSC). High levels of mineralization of the dissolved organic carbon and color removal of a synthetic NOM surrogate solution were achieved even under natural lab's lighting and ambient temperature and pressure, whereas the absence of radiation (in dark) was found to strongly affect the performance of the degradation. The photo-CWPO of NOM activated by the Al/Fe-PILC clay catalyst under visible light irradiation (LED lamp, 450 and $550 \mathrm{~nm}$ peaks) displayed a DOC mineralization of $72 \%$ and color removal of $73 \%$ in just $210 \mathrm{~min}$ of irradiation at neutral $\mathrm{pH}$, whereas both responses decayed under ultraviolet lightning $(\lambda: 365 \mathrm{~nm})$ to $41 \%$ and $58 \%$, respectively. This behavior is ascribed to formation of triplet states of natural organic matter $\left({ }^{3} \mathrm{NOM}^{*}\right)$ by absorption of visible light, which seems to synergistically improve the rate-determining step of the heterogeneous Fenton process, namely reduction of $\mathrm{Fe}^{3+}$ into $\mathrm{Fe}^{2+}$ on the surface of the clay catalyst. Interestingly, experiments performed at neutral and $\mathrm{pH} 3.0$ showed very similar efficiencies under visible light irradiation; these findings may really facilitate the application of the photo-CWPO process to assist conventional drinking water treatment plants in the removal of NOM before the typical disinfection by chlorine to produce safer drinking water.
\end{abstract}

Keywords: heterogeneous-photo Fenton; natural organic matter; Al/Fe-PILC; visible light photooxidation

\section{Introduction}

Natural organic matter (NOM) is defined as a complex matrix of organic compounds ubiquitous in all natural water sources [1]. NOM is a problem for drinking water production causing taste, odor and color, fouling of filtration membranes, promoting biological growth in water distribution, and as well-known precursor of carcinogenic and mutagenic disinfection byproducts (DBPs) [2].

Probably among the advanced oxidation processes (AOPs), the standard Fenton process is the more documented one $\left(\mathrm{Fe}^{2+} / \mathrm{H}_{2} \mathrm{O}_{2}\right)$ (Equations (1)-(3)), whose high activity is due to the generation of reactive oxygen species (ROS) through decomposition of $\mathrm{H}_{2} \mathrm{O}_{2}$ by dissolved transition metal ions, usually iron [3]. However, it displays mainly following drawbacks for real water treatment: (i) the dissolved iron catalyst cannot be easily recovered 
at the end of the process, generating sludge; and (ii) the process only operates efficiently within a narrow range of acid $\mathrm{pH}(\sim 3.0-4.0)$ [4].

$$
\begin{gathered}
\mathrm{Fe}^{2+}+\mathrm{H}_{2} \mathrm{O}_{2} \rightarrow \mathrm{HO}^{\bullet}+\mathrm{Fe}^{3+}+\mathrm{OH}^{-} \text {Fenton reaction } \\
\mathrm{Fe}^{3+}+\mathrm{H}_{2} \mathrm{O}_{2} \rightarrow \mathrm{HO}_{2}^{\bullet}+\mathrm{Fe}^{2+}+\mathrm{H}^{+} \text {Fenton }- \text { like reaction } \\
\mathrm{RH} \text { (organic substrate) }+\mathrm{ROS} \rightarrow \text { intermediates } \rightarrow \mathrm{CO}_{2}+\mathrm{H}_{2} \mathrm{O}+\text { by-products }
\end{gathered}
$$

On the other hand, the classic photo-Fenton process $\left(\mathrm{Fe}^{3+} / \mathrm{H}_{2} \mathrm{O}_{2}, h v\right)$ has shown to enhance the catalytic system mostly at wavelengths below $600 \mathrm{~nm}[5,6]$ (Equation (4)), whereas the photolysis of $\mathrm{H}_{2} \mathrm{O}_{2}$ may also take place as an additional source of $\mathrm{HO}^{\bullet}$ radicals under irradiation at wavelengths beneath $280 \mathrm{~nm}$ [6,7] (Equation (5)). Moreover, the instability of the dissolved metal at circumneutral $\mathrm{pH}$ and formation of sludge is not still solved by this photo-activated variant of the process.

$$
\begin{gathered}
{[\mathrm{Fe}(\mathrm{OH})]^{2+} \stackrel{h v}{\rightarrow} \mathrm{Fe}^{2+}+\mathrm{HO}^{\bullet}} \\
\mathrm{H}_{2} \mathrm{O}_{2} \stackrel{h v}{\rightarrow} 2 \mathrm{HO}^{\bullet}
\end{gathered}
$$

Thus, the heterogenization of the Fenton process by incorporating the active phase in a catalytic solid, the so-called catalytic wet peroxide oxidation (CWPO), does significantly overcome such issues, but a decreased oxidizing power remains as the $\mathrm{pH}$ approaches to that of real surface water streams (close to neutral). CWPO is based on the in-situ generation of reactive oxygen species (ROS: $\mathrm{HO}^{\bullet}, \mathrm{HO}_{2}{ }^{\bullet}, \mathrm{O}_{2}{ }^{\bullet-}$, etc.), often also called heterogeneousFenton process, in sufficient amounts to significantly mineralize even highly recalcitrant pollutants into carbon dioxide, water and some light carboxylic acids [8]. Moreover, although constituting a promising sustainable strategy to allow the solid catalyst to increase its reactivity by taking advantage of the solar irradiation, the CWPO process assisted by light, mainly by visible light, remains rather ignored. It should also be mentioned that only a few studies have been devoted to elucidating the heterogeneous photo-Fenton catalytic degradation of NOM [9-11], and none of them studied the role of iron-modified layered clays. The reason probably lies on the difficulty to remove the refractory fractions of NOM such as humic substances, as well as by the intrinsic structural complexity of NOM that leads to a poor understanding of its removal mechanism by advanced oxidation processes [12].

On the other hand, the $\mathrm{Al} / \mathrm{Fe}$-pillared interlayered clays (Al/Fe-PILCs) are a class of microporous solids stabilizing "pillars" of $\mathrm{Al} / \mathrm{Fe}$ mixed oxides whose main role is achieving the layered material to remain expanded, thus preventing its collapse [13]. The clay pillaring greatly improves the specific surface, microporous content and the chemical stability of the incorporated iron in the pillared material [14,15]; Al/Fe-PILCs are lowcost materials that have displayed low iron leaching in the CWPO degradation of phenol solutions (below $0.3 \mathrm{mg} / \mathrm{dm}^{3}$ ) [16]. The CWPO method activated by aluminum/iron pillared clays (Al/Fe-PILC) has shown to be an efficient AOP to remove synthetic NOM $\left(0.1-0.7 \mathrm{mg} / \mathrm{dm}^{3}\right)$ [17], as well as hazardous pathogens from drinking water treatment effluents [18] in absence of radiation; it implies negligible contribution of the dissolved active metal from the catalyst to the homogeneous, classic Fenton activation of the $\mathrm{H}_{2} \mathrm{O}_{2}$ added, and at the same time increased catalyst's lifetime. Khankhasaeva et al., 2020 [19] recently achieved the CWPO degradation (100\%) and carbon mineralization $(52 \%)$ of $p$ aminobenzenesulfanilamide (ABS) in the presence of an Fe-PILC-type catalyst assisted by UV irradiation $(\lambda: 254 \mathrm{~nm})$. According to the authors, the ability of ABS molecules to absorb light at 197 and $258 \mathrm{~nm}$ contributed to a synergistic effect between catalyst, $\mathrm{H}_{2} \mathrm{O}_{2}$, and irradiation to take place. In this regard, frequently used photocatalysts including $\mathrm{TiO}_{2}$ and $\mathrm{ZnO}$ require activation by UV-light. In attempting to overcome that limitation, the preparation, characterization and catalytic assessment of novel visible-light-active solid photo-catalysts have undergone a kind of booming in recent years [20,21]. 
As said, the use of Fe-modified pillared clays as catalysts of the heterogeneous Fenton process assisted by light has been just very scarcely studied. There are just a few reports about the performance exhibited by this kind of materials in photocatalytic applications [22,23]; the process is conducted under the mechanism briefly summarized in Equations ((6)-(9)). Under irradiance with photons of proper energy, the electrons in the valence band of a semiconductor deposited over the catalyst's surface get easily excited generating free electrons $e^{-}$and holes $h^{+}$(Equation (6)), which subsequently react with dissolved $\mathrm{O}_{2}$ and $\mathrm{H}_{2} \mathrm{O}$ to generate oxidizing species $\left(\mathrm{O}^{\bullet}, \mathrm{HO}^{\bullet} \mathrm{y} \mathrm{O}_{2}{ }^{\bullet-}\right.$ ) (Equations (7)-(9)) [21].

$$
\begin{gathered}
\text { Semiconductor } \stackrel{h v}{\rightarrow} e^{-}+h^{+} \\
e^{-}+\mathrm{O}_{2(a d s)} \rightarrow \mathrm{O}_{2(a d s)}^{\bullet-} \\
h^{+}+\mathrm{O}_{2(a d s)}^{\bullet-} \rightarrow 2 \mathrm{O}_{(a d s)}^{\bullet} \\
h^{+}+\mathrm{H}_{2} \mathrm{O}_{(a d s)} \rightarrow \mathrm{HO}^{\bullet}+\mathrm{H}^{+}
\end{gathered}
$$

Moreover, to the best of our knowledge, the use of the Al/Fe-PILC as photo-catalyst under visible light irradiation in the photo-CWPO process, has not yet been examined. Likewise, the NOM degradation by this catalytic system imposes to also consider the potential role played by the photosensitizing effect of the NOM itself on the overall photodegradation of dissolved organic pollutants [24].

The NOM in solution, and particularly dissolved humic substances impart a yellowish to brown color to most of natural waters. Thus, the photoactivity may be initiated by the absorption of light by NOM, nitrates, nitrites and several dissolved $\mathrm{Fe}^{3+}$ species leading to form several primary and secondary reactive species able to react with organic pollutants and NOM itself [25]. Li et al., 2017 [26] recently investigated the degradation of acetaminophen in NOM solutions under a $1700 \mathrm{~W}$ Xenon lamp (absolute intensity between 300 and $400 \mathrm{~nm}$ fixed at $40 \mathrm{~W} / \mathrm{m}^{2}$ ), pH 7.0 and $25^{\circ} \mathrm{C}$, reporting that triplet states of natural organic matter $\left({ }^{3} \mathrm{NOM}^{*}\right)$ played a dominant role in the photosensitized degradation of acetaminophen (acetaminophen degradation $>65 \%$ ). According to the authors, the main photochemical pathway involved the transfer of electrons from acetaminophen to the ${ }^{3} \mathrm{NOM}^{*}$ states. Despite of the extensively investigated NOM's photodegradation in different aquatic systems, the form by which NOM and the Al/Fe-PILC participate in the photo-CWPO process under ultraviolet or visible light at circumneutral $\mathrm{pH}$ has not been reported.

Therefore, this work was devoted to investigate the visible-light assisted photo-CWPO degradation of dissolved NOM in the presence of an Al/Fe-pillared clay catalyst. Several experiments were conducted to determine which part of the solar radiation (UV or Vis) would mostly contribute to promote the CWPO oxidation under different conditions of $\mathrm{pH}$ and radiation sources.

\section{Results and Discussion}

\subsection{Physicochemical Feautures of the Al/Fe-PILC Clay Catalyst}

The main structural and textural properties of the starting mineral and the Al/Fe-PILC clay catalyst are displayed in Table 1 . The X-ray diffraction analyses (XRD) showed the intercalation of Keggin-like polyoxocations was sufficiently pronounced to increase the basal spacing of the starting mineral stabilizing pillars of Al/Fe mixed oxides (Figure 1a). The observed signal $\left(6.12^{\circ} 2 \theta\right.$ equivalent to a basal spacing of $\left.1.44 \mathrm{~nm}\right)$ corresponding to the basal spacing $\left(\mathrm{d}_{001}\right)$ of the starting material is characteristic of smectites with compensating cations in their hydrated state. Meanwhile, it raised up to around $1.67 \mathrm{~nm}$ in the $\mathrm{Al} / \mathrm{Fe}-$ PILC clay catalyst, within the range of reported values for Al/Fe-pillared clays (1.26$1.86 \mathrm{~nm}$ ) [27]. 
Table 1. Main structural ant textural properties of the starting mineral and the pillared Al/Fe-PILC clay catalyst.

\begin{tabular}{|c|c|c|c|c|c|c|}
\hline \multirow[b]{2}{*}{ Material } & \multicolumn{6}{|c|}{ Physicochemical Properties } \\
\hline & $\begin{array}{c}\mathrm{d}_{001} \\
(\mathrm{~nm})^{\mathrm{a}}\end{array}$ & $\begin{array}{c}S_{B E T} \\
\left(\mathrm{~m}^{2} / \mathrm{g}\right)\end{array}$ & $\begin{array}{c}S_{\mu p} \\
\left(\mathrm{~m}^{2} / g\right)^{c}\end{array}$ & $\begin{array}{l}\mathrm{Fe}_{\text {content }} \\
(\% w / w)\end{array}$ & $\begin{array}{c}\mathbf{F e}_{\text {incorporated }} \\
(\% w / w)^{\mathrm{d}}\end{array}$ & $\begin{array}{c}\text { CEC } \\
(\mathrm{meq} / 100 \mathrm{~g})\end{array}$ \\
\hline $\begin{array}{l}\text { Starting } \\
\text { mineral }\end{array}$ & 1.44 & 51 & 26 & 9.96 & NA & 256 \\
\hline Al/Fe-PILC & 1.67 & 153 & 110 & 11.68 & 1.72 & 70 \\
\hline
\end{tabular}

${ }^{a} \mathrm{~d}_{001}$ : basal spacing determined by XRD; ${ }^{\mathrm{b}} \mathrm{S}_{\mathrm{BET}}$ : specific surface area; ${ }^{\mathrm{c}} \mathrm{S}_{\mu \mathrm{p}}$ : specific micropore's surface; ${ }^{\mathrm{d}} \mathrm{Fe}_{\text {incorporated }}$ : determined by atomic absorption spectroscopy; ${ }^{\mathrm{e}} \mathrm{CEC}$ : cationic exchange capacity. NA: not applicable.
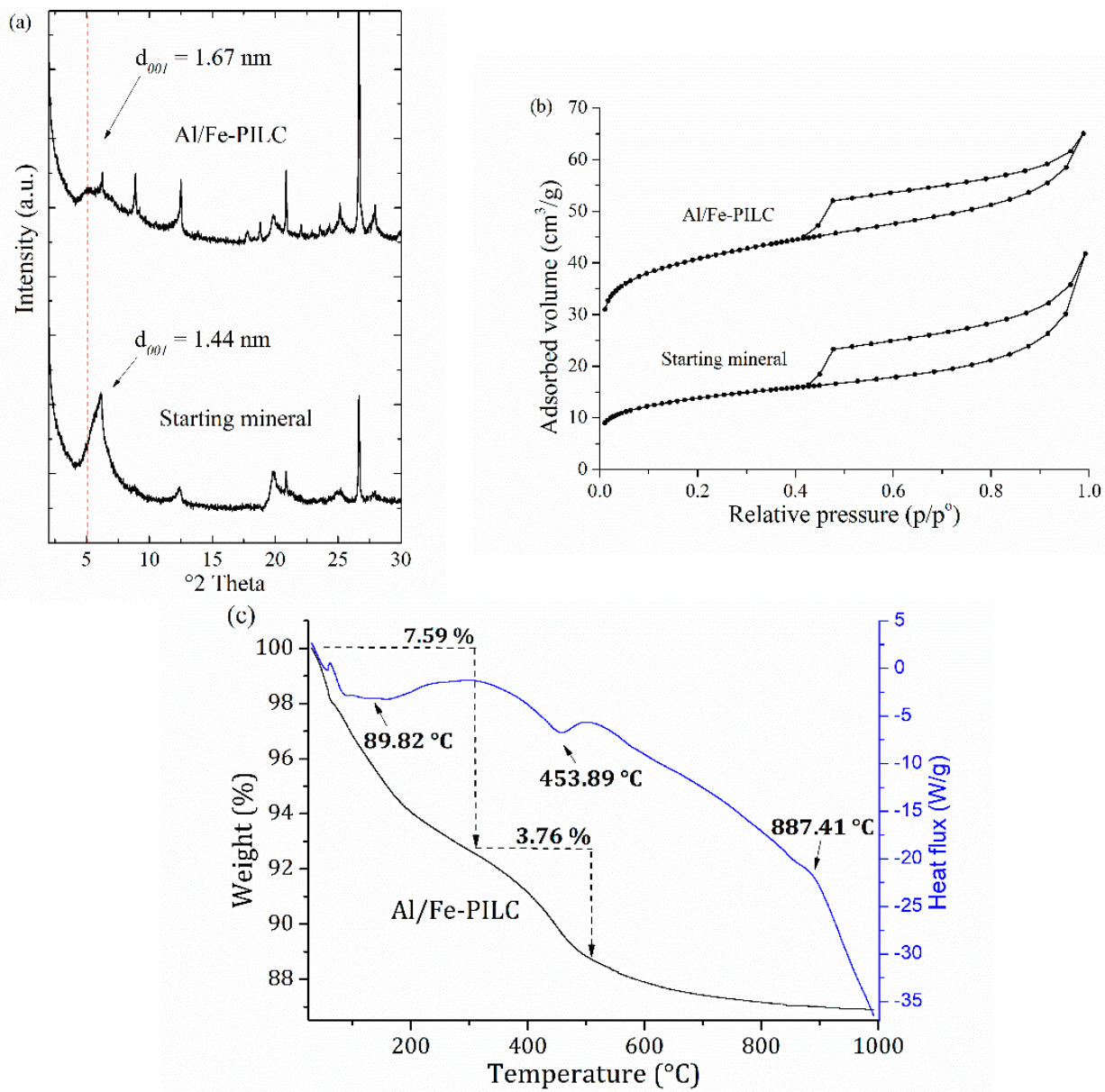

Figure 1. Physicochemical characteristics of the starting material and the Al/Fe-PILC clay catalyst: (a) Powder XRD patterns; (b) Nitrogen adsorption/desorption isotherms; (c) Simultaneous thermal analysis (TGA/DSC) of the Al/Fe-PILC catalyst.

It correctly matched with what is expected for the change in the textural properties. The adsorption-desorption isotherm (Figure 1b) of the Al/Fe-PILC catalyst displayed type I behavior in the low pressure range and type IV in the high pressure range, featuring significant formation of micropores and mesopores in the material as a consequence of the modification [27], while the starting mineral exhibited type IV according to International Union of Pure and Applied Chemistry system (IUPAC) [28]. Thus, the three-fold increased Brunauer-Emmett-Teller (BET) specific surface of the Al/Fe-PILC in comparison to the starting mineral was mainly represented in new micropores. The $\mathrm{H}_{3}$ hysteresis (Figure $1 \mathrm{~b}$ ) typical of slit-type pore morphology [29] demonstrated the clay catalyst preserved the layered pattern of the starting clay.

On the other hand, $1.72 \%(w / w)$ of Fe got incorporated by the pillaring procedure in the clay structure. In addition, the cation exchange capacity (CEC) decreased with 
respect to the starting material, which confirmed the pillaring process mainly took place by the exchange of the cations formerly present in the interlayer space of the clay and the stabilization of the mixed pillars no longer susceptible to be exchanged, providing chemical stability to the layered structure [30].

Finally, the simultaneous thermogravimetric and differential scanning calorimetry analysis (TGA/DSC) of the intercalated Al/Fe-PILC (before final calcination stage) displayed thermo-analytical patterns characteristic of Al/Fe-PILCs: (i) initial mass loss centered at approximately $90^{\circ} \mathrm{C}$ corresponding to desorption of coordinated and physisorbed water molecules; (ii) second endothermal event at $454^{\circ} \mathrm{C}$ related to a mass loss attributed to structural de-hydroxylation of the clay layers. (iii) Exothermal step around $887^{\circ} \mathrm{C}$ without mass loss ascribed to delamination.

\subsection{Photo-CWPO Degradation of Natural Organic Matter}

First of all, three preliminary experiments evidenced the effects of both natural lighting and air bubbling over the NOM degradation by the CWPO technology under optimal conditions of reaction previously determined, and neutral $\mathrm{pH}[17,31]$. Then, the photocatalytic CWPO of NOM was studied under either UV or Visible light irradiation and neutral $\mathrm{pH}$. Transversely, several control experiments were also carried out to measure the effects of $\mathrm{pH}$, catalyst's adsorption, dissolved iron and Fe content in the starting mineral, among others.

\subsubsection{CWPO Degradation of NOM under Optimal Conditions}

Experiments at Figure 2 configured an early evidence about the potential effect exerted by the natural lab's lighting and the air bubbling over the Al/Fe-PILC-catalyzed CWPO of natural organic matter. First of all, $89 \%$ of DOC mineralization and $95 \%$ of color removal were achieved by addition of just $30 \mathrm{mg} \mathrm{H}_{2} \mathrm{O}_{2} / \mathrm{dm}^{3}$, a fairly low dose in comparison with other reports. For example, Rezaee et al., 2014 [32] employing an optimal concentration of hydrogen peroxide of $100 \mathrm{mg} / \mathrm{dm}^{3}$ in the $\mathrm{UV} / \mathrm{H}_{2} \mathrm{O}_{2}$ degradation of NOM (initial DOC $4.0 \mathrm{mg} \mathrm{C} / \mathrm{dm}^{3}$ ) under $\mathrm{pH} 6.12$ reported $76.5 \%$ of DOC mineralization. In addition, the high levels of $\mathrm{DOC}$ and color removal under quite moderate conditions of $\mathrm{pH}$ and temperature demonstrated that CWPO can induce profound chemical modifications on NOM, where the heavier molecular weight compounds are transformed into smaller ones such as aldehydes and carboxylic acids, with significant evolution of $\mathrm{CO}_{2}$ throughout.

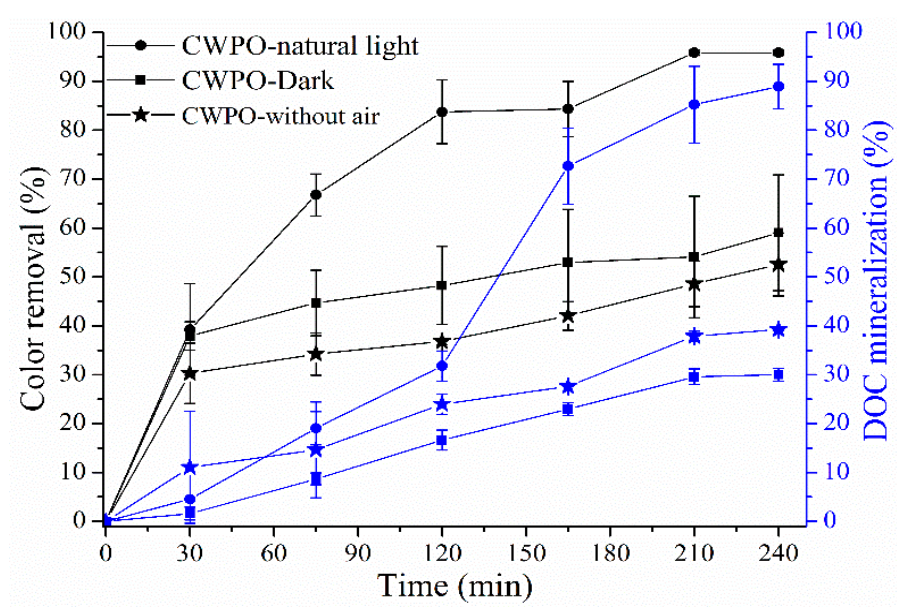

Figure 2. CWPO control experiments in the degradation of NOM: CWPO-natural light (CWPO at optimal conditions with $\mathrm{Al} / \mathrm{Fe}-\mathrm{PILC}$ catalyst under natural light); CWPO-Dark (CWPO under darkness); CWPO-without air ( $\mathrm{N}_{2}$ bubbling and natural lab's lighting). General conditions: $0.475 \mathrm{dm}^{3}$ of NOM solution; [NOM] $]_{0}: 7.0 \mathrm{mg} \mathrm{C} / \mathrm{dm}^{3} ; \mathrm{H}_{2} \mathrm{O}_{2}$ dose: $3.77 \mathrm{mg} \mathrm{H}_{2} \mathrm{O}_{2} / \mathrm{mg}$ DOC; [Al/Fe-PILC]: $3.81 \mathrm{~g} / \mathrm{dm}^{3} ; \mathrm{pH}: 7.0 ; \mathrm{T}=18.0 \pm 1.0^{\circ} \mathrm{C}$; ambient pressure $72 \mathrm{kPa}$. Error bars from standard deviations of three replicates. 
On the other hand, there was observed a remarkable depletion in both color removal (95\% to 59\%) and DOC mineralization (89\% to 30\%) when the catalytic experiment was carried out in dark conditions (Figure 2). It seriously suggested that light would be significantly enhancing the performance of the Al/Fe-PILC/CWPO catalytic system.

Finally, the control experiment without air bubbling (Figure 2) also led to further reduction in the color removal up to $52 \%$. Oxygen has been claimed to be involved in the Fenton mechanism by facilitating formation of ROS and allowing diffusion of carbon-centered free radicals following the Dorfman's mechanism [33]. However, the DOC mineralization displayed an opposite behavior, slightly increasing up to $39 \%$ against the experiment in dark. These somehow confusing trends about the role of oxygen in the catalytic system suggested that triplet states of NOM $\left({ }^{3} \mathrm{NOM}^{*}\right)$ might be involved under the influence of light, since dissolved oxygen is considered an efficient scavenger of excited triplet states of NOM $\left({ }^{3} \mathrm{NOM}^{*}\right)$, preventing their transformation to singlet oxygen [24], an important ROS in the degradation of several pollutants. Thus, without oxygen in the system, the concentration of singlet oxygen generated from ${ }^{3} \mathrm{NOM}^{*}$ would decrease [26]. Other control experiments (not shown) analyzed in a previous study [31] demonstrated the contributions of either the oxidizing agent $\left(\mathrm{H}_{2} \mathrm{O}_{2}\right)$, the catalyst adsorption or dissolved iron (homogeneous Fenton) to be negligible in order to explain the catalytic responses.

Accordingly, this set of preliminary experiments suggested important effects of light and air bubbling taking place in the degradation of NOM through the CWPO catalytic system in the presence of Al/Fe-PILCs. A priori, it established that the Al/Fe-PILC clay catalyst exhibits photocatalytic characteristics, possibly due to either or a combination of: (i) direct absorption of radiation by the active solid (purely photocatalytic activity), (ii) light absorption by the colored dissolved NOM (photo-sensitizing effect) [34] or (iii) taking into account that in both cases the catalytic process was assisted by hydrogen peroxide, the heterogeneous photo-Fenton process could be also involved. The main motivation of this study was just to determine which of these routes are mostly contributing to NOM's degradation under light irradiation by this catalytic system, and by means of what fraction of the natural sunlight (ultraviolet and/or visible).

\subsubsection{Photo-CWPO under Ultraviolet (UV) Irradiation}

Figure 3 displays the results of the photo-CWPO of NOM and the control experiments under UV light irradiation and neutral $\mathrm{pH}$. First of all, the CWPO experiment under UV light irradiation (UV-CWPO) exhibited a slightly higher DOC mineralization (41\%) respect to the Dark-CWPO experiment (30\%), and mainly through the final 30 min of irradiation. However, the color removal remained almost unchanged in both experiments close to $60 \%$. Meanwhile, the experiment performed under identical conditions, but using phenol (UV-CWPO-Phenol) instead of NOM, displayed both lower DOC removal and degradation in comparison to UV-CWPO, which probably obeyed to the highly bio-refractory character of phenol.

The UV-NOM, UV-Fe and UV- $\mathrm{H}_{2} \mathrm{O}_{2}$ control experiments displayed that neither straight NOM's photolysis, the photo-Fenton homogeneous reaction or the direct attack of the oxidizing reagent, respectively, could explain the responses recorded in the UV-photoCWPO experiment.

Both, the DOC mineralization and the color removal only in the presence of UV light (UV-NOM) were negligible, mainly because direct photolysis requires the UV-Vis absorption spectrum of NOM to overlap with the emission of the UV lamp, which did not happen in this case. Likewise, the homogeneous photo-Fenton control experiment (UV-Fe) exhibited greater DOC mineralization (18\%) than color removal $(6 \%)$; limited direct oxidation of the smaller, poorly colored fractions of NOM can be there inferred. The dissolved iron in the system interacted with UV light to favor photo reduction of $\mathrm{Fe}^{3+}$ into $\mathrm{Fe}^{2+}$, by which ROS generation from $\mathrm{H}_{2} \mathrm{O}_{2}$ became enhanced [35]. However, the DOC mineralization exhibited by this system was not that high under circumneutral $\mathrm{pH}$, where the dissolved iron is largely unstable; once again, the color removal was essentially disfavored by the 
classical homogeneous photo-Fenton under circumneutral $\mathrm{pH}$. Since almost quantitative precipitation of the dissolved iron was recorded in the UV-Fe experiment at final time of reaction, thus it can be also said that heterogeneous photo-Fenton under circumneutral $\mathrm{pH}$ was neither significantly promoted by the precipitated Fe oxy-hydroxides under the applied UV irradiation.
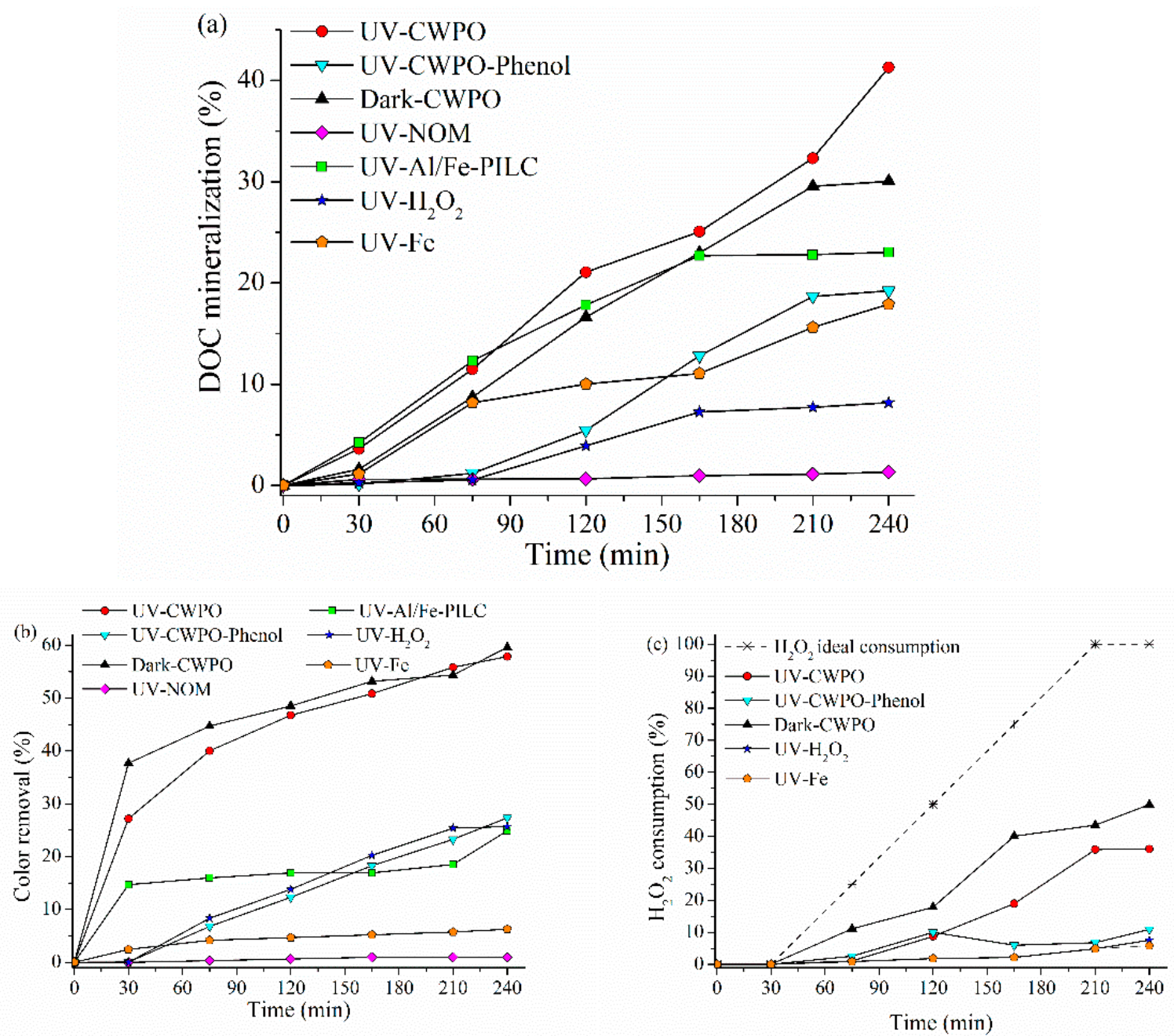

Figure 3. Photo-CWPO degradation of NOM (or phenol) under UV irradiation: (a) DOC mineralization, (b) color removal and (c) $\mathrm{H}_{2} \mathrm{O}_{2}$ consumption. UV light source $\lambda=365 \mathrm{~nm}$; [DOC $]_{0}: 7.0 \mathrm{mg} \mathrm{C} / \mathrm{dm}^{3}$ either represented from NOM surrogate or phenol; $\mathrm{H}_{2} \mathrm{O}_{2}$ dose: $3.77 \mathrm{mg} \mathrm{H}_{2} \mathrm{O}_{2} / \mathrm{mg} \mathrm{C}\left(30 \mathrm{mg} \mathrm{H}_{2} \mathrm{O}_{2} / \mathrm{dm}^{3}\right)$; [Al/Fe-PILC]: $3.81 \mathrm{~g} / \mathrm{dm}^{3}$; [ $\left.\mathrm{Fe}^{2+}\right]_{0}$ in UV-Fe experiment: $65 \mathrm{mg} / \mathrm{dm}^{3} ; \mathrm{pH}_{0}$ : 7.0; T: $20.0 \pm 1.0{ }^{\circ} \mathrm{C}$; ambient pressure $100 \mathrm{kPa}$; Fe leaching $<0.1 \mathrm{mg} / \mathrm{dm}^{3}$.

On the other hand, the experiment performed just in the presence of hydrogen peroxide and UV light $\left(\mathrm{UV}-\mathrm{H}_{2} \mathrm{O}_{2}\right)$ raised very low responses of DOC mineralization $(8.0 \%)$ and color removal $(26 \%)$, showing that hydroxyl radicals and other oxidizing species taking place in the photocatalytic system were not formed by the $\mathrm{H}_{2} \mathrm{O}_{2}$ photolysis, since the UV-A light source used $(\lambda 365 \mathrm{~nm})$ did not provide the UV radiation required for that, mostly at wavelengths below $280 \mathrm{~nm}[6,7]$. Therefore, the observed partial oxidation of NOM probably took place by ring opening of aromatic structures, cleavage of conjugated double bonded carbon structures, and reduction in the degree of aromatic substitution [36].

Finally, the UV-Al/Fe-PILC experiment (just UV light and the clay catalyst) achieved $23 \%$ of DOC mineralization and $25 \%$ of color removal; although both responses were in general higher than those obtained in the presence of the other control experiments, it could not be hypothesized that NOM's degradation responses here recorded could be mostly explained by simple adsorption of the organic substrates over the catalyst's surface 
and/or direct photocatalytic effect driven by the interaction between the catalyst and the UV irradiation.

Conversely, the consumption of $\mathrm{H}_{2} \mathrm{O}_{2}$ (Figure 3c) showed the opposite behavior: higher peroxide consumption was recorded in the Dark-CWPO experiment (50\%) than in the UV- irradiated one $(36 \%)$, whereas similar DOC mineralization and color removal were recorded by the UV-CWPO. Since the UV-Al/Fe-PILC experiment showed a middle DOC mineralization, and the UV lamp used in this study was a low power one (18 watts) in comparison to other commonly reported in literature in the range of 50 to 400 watts $[9,26,37]$, alongside experimental setups usually including more than one lamp [38], it does not allow to straightforwardly rule out a possible contribution of UV-activated photocatalytic activity of the $\mathrm{Al} / \mathrm{Fe}-\mathrm{PILC}$ catalyst.

\subsubsection{Photo-CWPO under Visible (Vis) Irradiation}

Figure 4 exposes the results obtained for the visible-light assisted photo-CWPO of $\mathrm{NOM}$ or phenol, and the corresponding control experiments. Firstly, all catalytic responses increased considerably for the Vis-CWPO experiment in comparison with the UV-CWPO experiment; both DOC mineralization and color removal achieved maximum levels exceeding $70 \%$, and the peroxide consumption was also enhanced to $56 \%$.
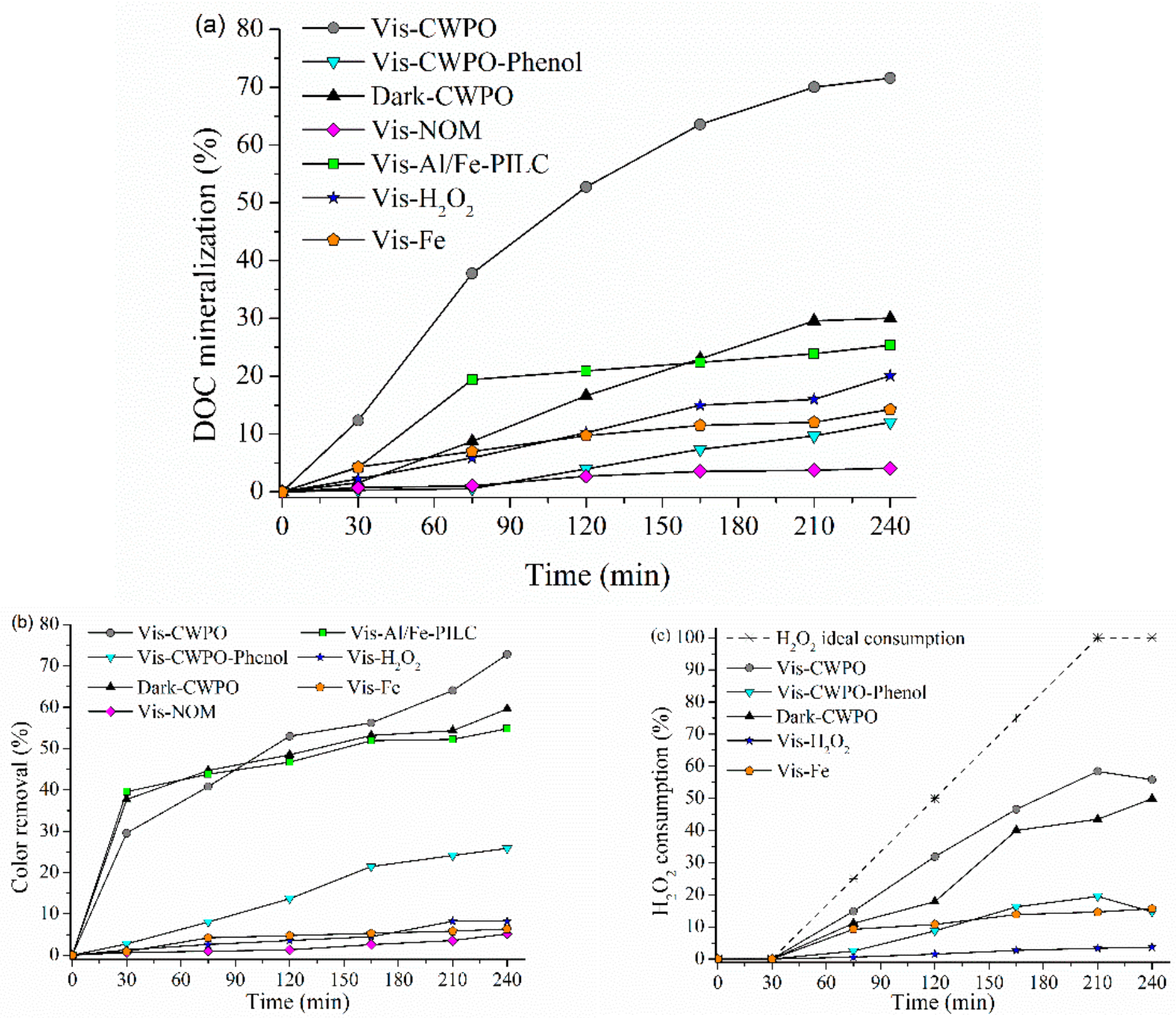

Figure 4. Photo-CWPO degradation of NOM (or phenol) under visible light irradiation: (a) DOC mineralization, (b) color removal and, (c) $\mathrm{H}_{2} \mathrm{O}_{2}$ consumption. Visible light source: steepest wavelengths at 450 and $550 \mathrm{~nm}$; [DOC] $]_{0}: 7.0 \mathrm{mg}$ $\mathrm{C} / \mathrm{dm}^{3}$ either represented by the NOM surrogate or phenol; $\mathrm{H}_{2} \mathrm{O}_{2}$ dose: $3.77 \mathrm{mg} \mathrm{H}_{2} \mathrm{O}_{2} / \mathrm{mg} \mathrm{C}\left(30 \mathrm{mg} \mathrm{H}_{2} \mathrm{O}_{2} / \mathrm{dm}^{3}\right)$; $[\mathrm{Al} / \mathrm{Fe}-$ PILC]: $3.81 \mathrm{~g} / \mathrm{dm}^{3} ;\left[\mathrm{Fe}^{2+}\right]_{0}$ in Vis-Fe experiment: $65 \mathrm{mg} / \mathrm{dm}^{3} ; \mathrm{pH}_{0}$ : 7.0; T: $20.0 \pm 1.0{ }^{\circ} \mathrm{C}$; ambient pressure $100 \mathrm{kPa}$; Fe leaching $<0.1 \mathrm{mg} / \mathrm{dm}^{3}$. 
Even though the direct visible irradiation over NOM (Vis-NOM) displayed pretty low DOC mineralization ( 4\%, Figure $4 a)$, it was slightly higher than that obtained under UV light (1\%, Figure 3a). Similar situation can be seen for the color removal (Figure $4 b$ ). It suggests the visible light irradiation can trigger molecular alterations on chromophores of the dissolved natural organic matter by breaking both aromatic rings and high molecular weight chromophores into low molecular weight residues [39]. Probably this is why NOM exerts an important influence on the pathways of transformation of organic pollutants induced by light in natural waters [40]. Similar behavior was observed by comparison of UV- $\mathrm{H}_{2} \mathrm{O}_{2}$ and Vis- $\mathrm{H}_{2} \mathrm{O}_{2}$ control experiments: the DOC mineralization under visible light irradiation was more than twice the one obtained under UV light, but the color removal strongly decreased from close to $25 \%$ under UV to around $10 \%$ under visible-light. It suggests that NOM under visible light promoted formation of additional ROS species with participation of $\mathrm{H}_{2} \mathrm{O}_{2}$ [41]. Nevertheless, probably the photoactivation of NOM into excited states delayed the oxidation of the more strongly absorptive chromophores in absence of the clay catalyst.

On the other hand, in order to estimate the effect exerted by the heterogeneous photo-Fenton pathway on the degradation of organics in the presence of the visible-light irradiation without NOM being involved, the Vis-CWPO-phenol experiment was performed under identical conditions but absence of NOM. In spite of the obvious different reactivity of the NOM surrogate in comparison to phenol against the ROS generated, it can be easily observed a very low DOC mineralization of phenol in absence of NOM. Even though it does not allow to fully rule out a heterogeneous photo-Fenton contribution on the enhanced degradation of NOM under visible light irradiation, it strongly suggest that other phenomena should be also involved. In the case of the homogeneous photo-Fenton control experiment, as already observed in the presence of UV light, under visible light irradiation both very low DOC mineralization (14\%) and color removal (6\%) were found. It confirms the classical homogeneous photo-Fenton reaction being strongly inhibited to produce ROS at circumneutral $\mathrm{pH}$, mainly because of the precipitation of the dissolved metal. Meanwhile, the adsorption together with the purely photocatalytic effect of the $\mathrm{Al} / \mathrm{Fe}$ PILC catalyst (Vis-Al/Fe-PILC) just in the presence of visible light irradiation showed $25 \%$ of apparent DOC mineralization, comparable with the results of UV light, but the color removal strongly increased from $25 \%$ (UV light) to $55 \%$ under visible light; it is difficult to explain this behavior solely based on the results obtained in this work, and hence it should be further and deeper investigated in order to elucidate what happens between NOM's chromophores, visible light and the Al/Fe-PILC clay catalyst seriously altering the adsorption of these complex pollutants. Nevertheless, as the DOC mineralization remained almost constant, it can be hypothesized that no extra oxidizing species were generated by the system without participation of peroxide.

On the other hand, the iron content naturally occurring in the framework of the starting clay mineral (SM, Table 1) showed the following in brief (Table 2): (i) the DOC mineralization of the contaminant was not significantly promoted by the starting material in the presence of either UV-, visible- or no irradiation within the assessed range of $\mathrm{pH}$ values; (ii) both, the low DOC mineralization levels (3\%-13\%) and $\mathrm{H}_{2} \mathrm{O}_{2}$ consumptions $(5-16 \%)$ at neutral $\mathrm{pH}$ allow to infer that no significant concentrations of ROS were formed; (iii) only in the presence of the starting mineral (UV-SM and Vis-SM essays), negligible consumption of the oxidizing reagent was detected. Hence, the high measured efficiency of the photo-CWPO reaction in the presence of the Al/Fe-PILC clay catalysts must be fairly related to the iron content incorporated in the layered structure through the pillaring procedure [14], where the effect of the natural content of iron in the starting mineral can be neglected for practical purposes. 
Table 2. Photo-CWPO degradation of NOM by the starting mineral clay (SM).

\begin{tabular}{cccc}
\hline Test $^{\text {a }}$ & DOC Mineralization (\%) & Color Removal (\%) & H $_{\mathbf{2}} \mathbf{O}_{\mathbf{2}}$ Consumption (\%) \\
\hline Dark-CWPO-SM & 9 & 27 & 2 \\
\hline UV-SM-NOM & 4 & 6 & NA \\
Vis-SM-NOM & 5 & 5 & NA \\
UV-SM-H O $_{2}$ & NA & NA & $\sim 0$ \\
Vis-SM-H $\mathrm{O}_{2}$ & $\mathrm{NA}$ & $\mathrm{NA}$ & $\sim 0$ \\
\hline UV-CWPO-SM-pH 3.0 & 11 & 78 & 0 \\
Vis-CWPO-SM-pH 3.0 & 12 & 90 & 4 \\
UV-CWPO-SM-pH 7.0 & 3 & 34 & 5 \\
Vis-CWPO-SM-pH 7.0 & 13 & 24 & 16 \\
UV-CWPO-SM-pH 9.0 & 5 & 28 & 17 \\
Vis-CWPO-SM-pH 9.0 & 4 & 29 & 18 \\
\hline
\end{tabular}

a The experiments were performed at $\mathrm{pH} 7.0$ unless specified different. UV light source $\lambda=365 \mathrm{~nm}$; Visible light source: steepest

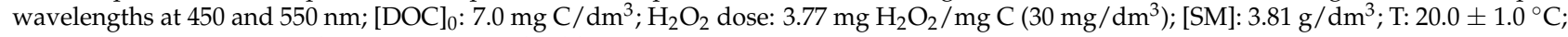
atmospheric pressure: $100 \mathrm{kPa}$. NA: Not applicable.

Thus, as above mentioned the NOM degradation under visible light irradiation considerably increased mainly in terms of dissolved carbon mineralization when $\mathrm{H}_{2} \mathrm{O}_{2}$ was added (Vis-CWPO, Figure 4), where several side effects have been disregarded to explain it. It is also noteworthy that leached concentrations of Fe in solution in the presence of either $\mathrm{Al} / \mathrm{Fe}-\mathrm{PILC}$ (below $0.1 \mathrm{mg} / \mathrm{dm}^{3}$ ) or the starting mineral SM (below $0.3 \mathrm{mg} / \mathrm{dm}^{3}$ ) were negligible in comparison with the one used in the control experiments UV-Fe and Vis-Fe $\left(65 \mathrm{mg} / \mathrm{dm}^{3}\right)$. It may arise on additional, more efficient pathways of ROS generation becoming available, as well as meanwhile probably oxidizing species other than only $\mathrm{HO}^{\bullet}$ and $\mathrm{HO}_{2}{ }^{\bullet} / \mathrm{O}_{2}{ }^{\bullet-}$ radical species also occurred in the presence of $\mathrm{H}_{2} \mathrm{O}_{2}$ and the $\mathrm{Al} / \mathrm{Fe}-\mathrm{PILC}$ clay catalyst at circumneutral $\mathrm{pH}$ [42]; a combination of the following may be took place: (i) enhanced photo-reduction of $\mathrm{Fe}^{3+}$ into $\mathrm{Fe}^{2+}$ in the clay catalyst just induced by visible light absorption [35] and (ii) ${ }^{3} \mathrm{NOM}^{*}$ states easily accessible by $\mathrm{NOM}^{\prime}$ 's visible light absorption [40,43], which in the presence of dissolved oxygen produced singlet oxygen $\left({ }^{1} \mathrm{O}_{2}\right)[44,45]$. However, based on the control experiments none of them alone were significant in DOC mineralization or color removal. In the first case, the band-gap of iron oxides allows to anticipate that electron-hole recombination should be rather more significant than iron photo-reduction; recently a band-gap of an iron-modified rectorite was reported to be around $2.01 \mathrm{eV} \mathrm{[42].} \mathrm{Regarding} \mathrm{second} \mathrm{possibility,} \mathrm{concentrations} \mathrm{of} \mathrm{singlet} \mathrm{oxygen} \mathrm{created}$ from dissolved oxygen have not been found comparable to those from $\mathrm{H}_{2} \mathrm{O}_{2}$ [46]. In the same sense, it's been recently reported that NOM absorbs sunlight to form a singlet excited state $\left({ }^{1} \mathrm{NOM}^{*}\right)$; immediately a small fraction of the ${ }^{1} \mathrm{NOM}^{*}$ transfers to a triplet excited state $\left({ }^{3} \mathrm{NOM}^{*}\right)$ through intersystem crossing (ISC), which in turn react with dissolved oxygen by energy transfer to produce singlet oxygen $\left({ }^{1} \mathrm{O}_{2}\right)[47,48]$. Then, probably the photons absorbed by the NOM chromophores caused their excitation to ${ }^{1} \mathrm{NOM}^{*}$ and ultimately to $\left({ }^{3} \mathrm{NOM}^{*}\right)[49,50]$, followed by production of reducing radical intermediates, which further reacted with dissolved oxygen to yield superoxide anions $\left(\mathrm{O}_{2}{ }^{\bullet-}\right)$ [51].

Merino et al., 2021 [52] recently reported that the soil organic matter can act as electron donor to iron reducing bacterial cells, where NOM may serve as an electron shuttle to reduce $\mathrm{Fe}^{3+}$ into $\mathrm{Fe}^{2+}$. This process is also part of the mechanisms usually displayed by the Fe-reducing microorganisms, including electron transfer to minerals by using either Fe-chelating compounds or electron-shuttling molecules like compounds exogenously provided by NOM [53]. Humic acids present in NOM have been reported to display high electron-acceptor capacities between 800 and $2000 \mu \mathrm{mol} / \mathrm{g}$ [53]; quinones, abundant groups in humic acids, have been reported as the most active groups in the redox chemistry of NOM by playing a key role as mediators of electron transfer in the reduction of iron $\mathrm{Fe}^{3+}$ attached to the goethite's surface [54], where aniline and phenolic are other abundant groups that also exhibit electron-donating properties [40,55]. Bauer et al., 2009 [56] also 
claimed the electron donation of NOM to be capable of reducing crystalline minerals such as goethite or hematite phases containing $\mathrm{Fe}^{3+}$, where specific interactions between $\mathrm{Fe}^{3+}$ on the mineral's surface and NOM influences the electron transfer process. In addition, it has been extensively reported [57-59] that NOM and iron can form complexes, and the reduction of iron can occur even if the metal is part of the complex; NOM can act as a ligand towards $\mathrm{Fe}^{3+}$, and NOM's composition, concentration, aromatic character and presence of complex compounds highly impact the reactivity of the Fe-organic associations [53].

Consequently, we hypothesize a synergistic mechanism to explain the significantly enhanced visible-light mediated photo-CWPO oxidation of NOM. As abovementioned, humic acids are redox-active compounds that can serve as electron shuttles reducing a variety of Fe (III) minerals [60]. Thus, under visible-light irradiation probably an electronic transfer takes place from ${ }^{3} \mathrm{NOM}^{*}$ excited states promoting the reduction of $\mathrm{Fe}^{3+}$ into $\mathrm{Fe}^{2+}$ (Figure 5), which is the well-known slower, rate-determining step of the Fenton process. Here it is noteworthy, that one of the main advantages attributed to Al/Fe-PILCs catalyzing the heterogeneous Fenton reaction has been the high specific, microporous surface where the $\mathrm{Fe}^{\mathrm{n}+}$ species get stabilized within the layered structure through the mixed $\mathrm{Al} / \mathrm{Fe}$-oxide pillars, presumably mostly exposed on their surface.

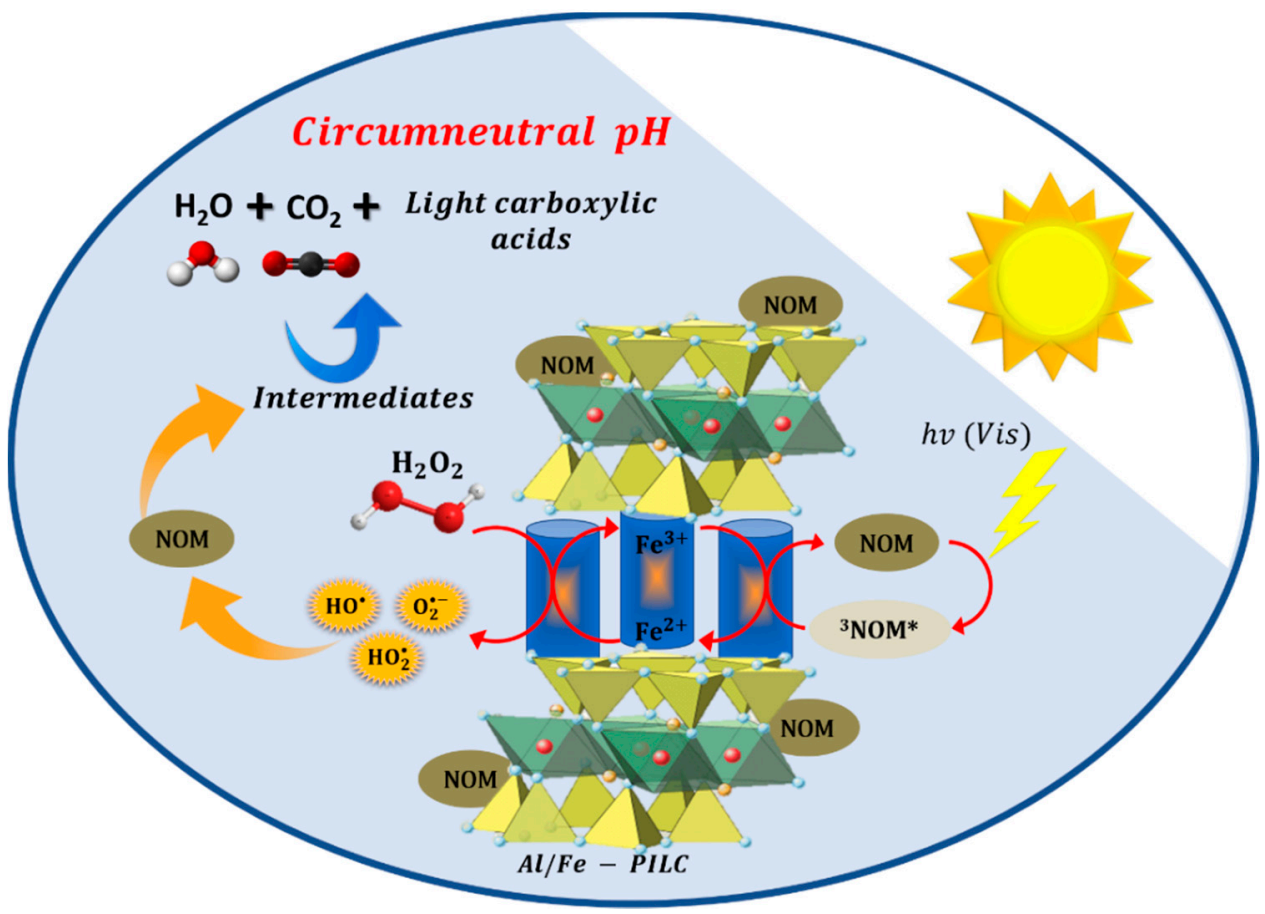

Figure 5. Proposed mechanism for the self-promoted visible-light enhanced photocatalytic wet peroxide oxidation of NOM by improved reduction of surface $\mathrm{Fe}^{3+}$ into $\mathrm{Fe}^{2+}$ in $\mathrm{Al} / \mathrm{Fe}-$ pillared clays.

Then, the manner by which Fe and NOM can interact on the catalyst's surface is a key to understand the proposed phenomenon. Orbital overlap may occur between NOM and iron, however, in the case where the electrons could not be transferred from NOM to iron due to different spin multiplicity, formation of a complex adduct by taking advantage of the chelating power of NOM is other plausible pathway [61]. Hence, it can be considered that once iron gets reduced on the catalyst's surface, the classical Fenton process becomes accelerated from the typical reaction of $\mathrm{Fe}^{2+}$ with $\mathrm{H}_{2} \mathrm{O}_{2}$ (Figure 5). The overall effect then increased the $\mathrm{H}_{2} \mathrm{O}_{2}$ conversion rate promoting an enhanced heterogeneous Fenton process. The generated ROS then quickly back-attacked the NOM and converted it into light intermediates and by products displaying carboxylic acids and other partially oxidized organic functionalities. 


\subsubsection{PH Effect in the Visible-Light Enhanced CWPO}

A photo-CWPO degradation of NOM was carried out at different starting $\mathrm{pH}$ values (3.0, 7.0 and 9.0; Figure 6). As expected, either experiments under ultraviolet or visible radiation at $\mathrm{pH} 3.0$ exhibited the highest DOC mineralization (76\%) and color removal (93 and $86 \%$ for UV and Vis radiation, respectively). Furthermore, the visible light experiment at $\mathrm{pH} 3.0$ showed significantly higher $\mathrm{H}_{2} \mathrm{O}_{2}$ consumption (62\%) than the UV experiment $(34 \%)$ at the same $\mathrm{pH}$, which agrees with the control experiments $\mathrm{UV}-\mathrm{H}_{2} \mathrm{O}_{2}$ and $\mathrm{Vis}-\mathrm{H}_{2} \mathrm{O}_{2}$ previously analyzed. No significant differences were observed between ultraviolet and visible light in terms of either DOC mineralization or color removal at $\mathrm{pH}$ 3.0. In this sense, Clarizia et al., 2017 [62] determined the optimal operating $\mathrm{pH}$ value for the photo-Fenton reaction catalyzed by dissolved $\mathrm{Fe}^{2+}$ in terms of DOC mineralization to be around 2.8, highlighting the heterogeneous system to be fairly less sensitive against the $\mathrm{pH}$ of reaction and efficient in pollutant's removal.

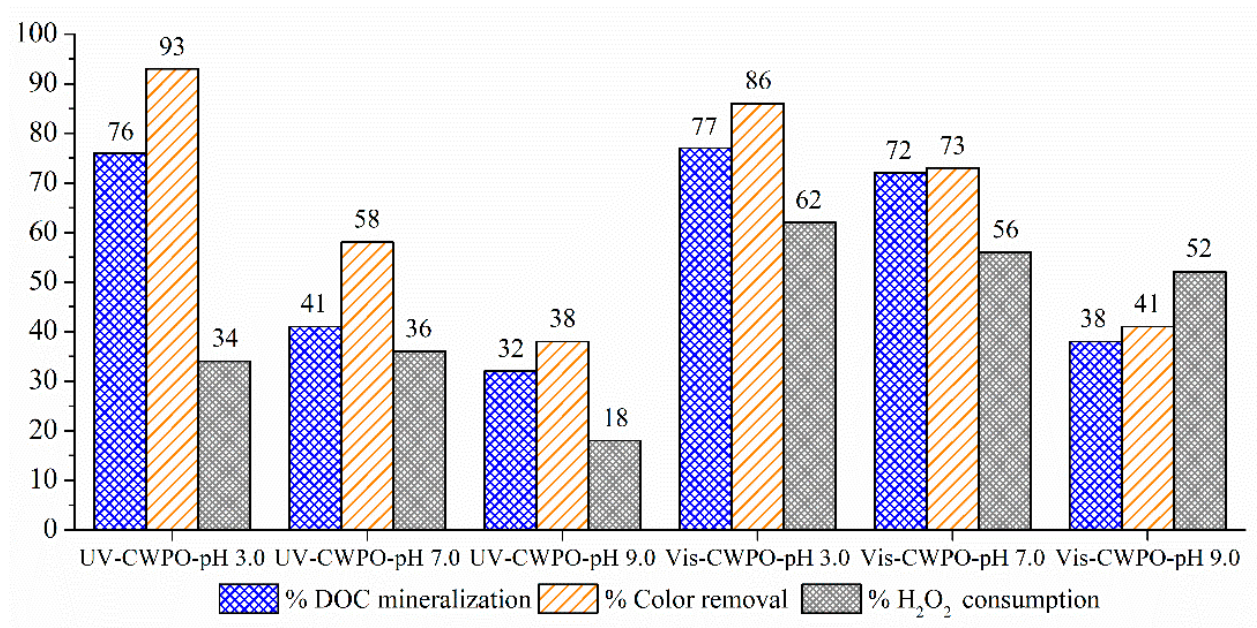

Figure 6. UV- and visible-light assisted photo-CWPO at three different initial $\mathrm{pH}$ values (3.0, 7.0 and 9.0). UV light source $\lambda=365 \mathrm{~nm}$; Visible light source: steepest wavelengths at 450 and $550 \mathrm{~nm}$; [DOC] $0: 7.0 \mathrm{mg} \mathrm{C} / \mathrm{dm}^{3} ; \mathrm{H}_{2} \mathrm{O}_{2}$ dose: $3.77 \mathrm{mg} \mathrm{H}_{2} \mathrm{O}_{2} / \mathrm{mg} \mathrm{C}\left(30 \mathrm{mg} / \mathrm{dm}^{3}\right) ;[\mathrm{Al} / \mathrm{Fe}-\mathrm{PILC}]: 3.81 \mathrm{~g} / \mathrm{dm}^{3}$; T: $20.0 \pm 1.0^{\circ} \mathrm{C}$; atmospheric pressure: $100 \mathrm{kPa}$. Fe leaching $<0.1 \mathrm{mg} / \mathrm{dm}^{3}$.

On the other hand, interestingly, the experiments under visible light irradiation at $\mathrm{pH}$ 7.0 and $\mathrm{pH} 3.0$ revealed fairly similar efficiencies in terms of all DOC mineralization (72\%), color removal $(73 \%)$, and $\mathrm{H}_{2} \mathrm{O}_{2}$ consumption (56\%). Thus, the visible-light induced improvement of the CWPO process may very efficiently offset the well-known negative effect of the $\mathrm{pH}$ increase on the performance of the Fenton process; in other words, in the presence of NOM's chromophores and visible light the CWPO process may perform degradation of organic pollutants at circumneutral $\mathrm{pH}$, almost as efficient as the classical homogeneous Fenton process at $\mathrm{pH}$ close to 3.0. Finally, the efficiency of the catalytic treatment dramatically dropped at $\mathrm{pH}$ 9.0, which can be mainly attributed to $\mathrm{H}_{2} \mathrm{O}_{2}$ disproportionation into water and oxygen [61], strongly favored at so that basic $\mathrm{pH}$ values.

The enhanced CWPO process by visible light under pretty mild conditions of ambient temperature and pressure, alongside natural $\mathrm{pH}$, may boost this technology as a quite promising and attractive alternative in the treatment of surface waters to strongly deplete dissolved NOM before chlorination; it eventually may allow producing safer drinking water, by strongly preventing formation of hazardous disinfection by-products, where NOM has been widely recognized precursor [8], even in tiny concentrations [63]. Several advantages can be devised for application of the visible-light enhanced CWPO in the degradation of dissolved NOM in the presence of Al/Fe-PILCs: (i) the clay catalyst is quite cheap and accessible from widely available clay minerals; (ii) the heterogeneous Fenton process prevents formation of sludge; (iii) solar light may strongly promote the degradation of dissolved NOM in proper translucent reacting units; (iv) the process's efficiency of the 
photo-enhanced AOP in terms of carbon mineralization over natural, circumneutral influent streams is quite comparable to the one performed in the optimal range of acid $\mathrm{pH}$ values typical of the Fenton process ( 3.0-4.0); (v) since the typical concentrations of dissolved NOM in natural surface water samples supplying drinking water facilities usually do not exceed some $\mathrm{mg}$ DOC $/ \mathrm{dm}^{3}$, the operating costs of implementing a CWPO unit to assist a drinking water treatment plant, mainly regarded to the required dose of hydrogen peroxide per unit mass of DOC, could be anticipated to be rather low.

\section{Materials and Methods}

\subsection{Materials}

Poly(acrylic acid) analytical standard (PAA) (average $\mathrm{M}_{\mathrm{n}}$ 130,000); Poly(sodium 4 styrenesulfonate) solution (PSS1) (average $\mathrm{M}_{\mathrm{w}}$ 1,000,000, 30\% in $\mathrm{H}_{2} \mathrm{O}$ ); Poly(sodium $4-$ styrenesulfonate) solution (PSS2) (average $\mathrm{M}_{\mathrm{W}}$ 200,000, 25\% in $\mathrm{H}_{2} \mathrm{O}$ ); humic acid (HA) $\left(\mathrm{M}_{\mathrm{W}}\right.$ 1,000,000); Polygalacturonic acid (PGUA) $\left(\mathrm{M}_{\mathrm{r}} 25,000-50,000, \geq 90 \%\right.$, enzymatic), all Sigma-Aldrich ${ }^{\circledR}$ with the following distribution: PAA $20.0 \%$, PSS1 12.5\%, PSS2 12.5\%, PGUA $30.0 \%$ y HA $20.0 \%$ were used to prepare the synthetic NOM surrogate solution according to the methodology previously reported by Garcia et al., 2021 [17] and Ordoñez et al., 2019 [18]. $\mathrm{NaOH}\left(\geq 99 \%\right.$, Merck $\left.{ }^{\circledR}\right), \mathrm{H}_{2} \mathrm{SO}_{4}$ (Panreac, 98\%), $\mathrm{FeSO}_{4} .7 \mathrm{H}_{2} \mathrm{O}(\geq 99.95 \%$, Panreac), $\mathrm{H}_{2} \mathrm{O}_{2}$ (30\%, Sigma-Aldrich), $\left(\mathrm{NH}_{4}\right)_{6} \mathrm{Mo}_{7} \mathrm{O}_{24} \cdot 4 \mathrm{H}_{2} \mathrm{O}$ (Merck, $81 \%-83 \%$ ), KI (Carlo Erba, 99.5\%) were used in the CWPO catalytic test. All used as received.

\subsection{Al/Fe-PILC Catalyst}

The pillared clay catalyst (Al/Fe-PILC) was prepared at $1.5 \mathrm{~kg}$ with mixed $\mathrm{Al} / \mathrm{Fe}$ polycations from highly concentrated precursors and technical grade reagents. The particle size was $250 \mu \mathrm{m}$ (60-mesh) to facilitate its separation from the reaction medium. Detailed procedure of preparation is available elsewhere [14,15].

\section{Physicochemical Characterization of the Al/Fe-PILC Catalyst}

Powder X-Ray Diffraction (XRD) patterns were recorded in the range $\left(2-70{ }^{\circ} 2 \theta\right)$ in a Bruker D8 Advance diffractometer at $40 \mathrm{kV}$ and $30 \mathrm{~mA}$ under scanning rate of $2^{\circ}(2 \theta) / \mathrm{min}$, using filtered $\mathrm{CuK} \alpha$ radiation $(\lambda: 1.5416 \AA)$, in order to determine the effect of the pillaring procedure over the starting clay's basal spacing $\mathrm{d}_{001}$.

The textural properties of the starting mineral and the Al/Fe-PILC catalyst were determined through the $\mathrm{N}_{2}$ adsorption-desorption isotherm at $-196^{\circ} \mathrm{C}$ in a wide range of relative pressures $\left(10^{-4}\right.$ to $\left.1.0 \mathrm{mmHg}\right)$ in a Micromeritics 3-Flex analyzer, on 100 to 200 mg of the previously degassed samples by means of two steps: $90{ }^{\circ} \mathrm{C}$ for $1 \mathrm{~h}$ and then 300 ${ }^{\circ} \mathrm{C}$ for $12 \mathrm{~h}$, under a heating ramp of $10^{\circ} \mathrm{C} / \mathrm{min}$. The specific surfaces were calculated using the multipoint Brunauer-Emmett-Teller (BET) method and the criteria of the Keii and Rouquerol model; the external surfaces and the volumes of micropores were calculated by the $t$-plot method, according to the equation of statistical thickness proposed by Harkins and Jura using equally distributed 9 points within a thickness range between $4.5 \AA$ and $5.5 \AA$.

The amount of iron incorporated in the Al/Fe-PILC catalyst was determined by acid digestion of the material and measured by atomic absorption spectroscopy in a Thermo Scientific ICE 3000 analyzer (Series Spectrometer) (detection limit: $0.0043 \mathrm{mg} / \mathrm{dm}^{3}$ ).

In order to determine the pattern of weight loss and change in structural properties upon heating, a simultaneous thermogravimetric and differential scanning calorimetry analysis (TGA/DSC) of the Al/Fe-PILC clay catalyst was made in a SDT Q600 TA Instruments apparatus. The measurement was performed on around $20 \mathrm{mg}$ of the interlayered clay (before the final step of annealing typical of the clay pillaring procedure), by heating under a flow of $100 \mathrm{~cm}^{3} / \mathrm{min}$ of air zero $2.0\left(99.99 \%\right.$, Cryogas $\left.{ }^{\circledR}\right)$, from RT to $60{ }^{\circ} \mathrm{C}$ using a ramp of $5.0{ }^{\circ} \mathrm{C} / \mathrm{min}$ and then at $10{ }^{\circ} \mathrm{C} / \mathrm{min}$ to $1000^{\circ} \mathrm{C}$.

The cationic exchange capacity (CEC) of the starting mineral and the final catalyst was determined by treating the materials with a $2.0 \mathrm{~mol} / \mathrm{dm}^{3}$ ammonium acetate solution 
(1.0\% $w / v$ suspension). The cation exchange reaction was carried out at room temperature, with constant stirring for $24 \mathrm{~h}$ and renewing the ammonium acetate solution after $12 \mathrm{~h}$. Then, the solids were washed by centrifugation until the end of acetates, to latter determine the ammonium content by micro-Kjeldahl analysis.

\subsection{Photo-CWPO Tests}

The photocatalytic experiments were carried out using the setup of Figure 7 . The tests were carried out at atmospheric pressure $(100 \mathrm{kPa})$ and room temperature $\left(20.0 \pm 1.0^{\circ} \mathrm{C}\right)$, in a cylindrical photoreactor cell made of Pyrex glass. The initial $\mathrm{pH}$ value of an either NOM or phenol solution was adjusted to 3.0, 7.0 or 9.0 (drops of $\mathrm{NaOH} 0.005 \mathrm{~mol} / \mathrm{dm}^{3}$ or $\mathrm{H}_{2} \mathrm{SO}_{4} 0.005 \mathrm{~mol} / \mathrm{dm}^{3}$ ) to examine the effect of $\mathrm{pH}$ on the photodegradation, but it was no longer controlled but just recorded. Either a PLL18W Philips lamp was used for UV irradiation $\left(6 \mathrm{~mW} / \mathrm{cm}^{2}\right.$ at $\left.365 \mathrm{~nm}\right)$ or a LED lamp $\left(160 \mathrm{~mW} / \mathrm{cm}^{2}\right.$ measured between 400-800 nm, steepest emissions at 450 and $550 \mathrm{~nm}$ ) for visible radiation, at the bottom of the reactor. Previously established optimal conditions for the CWPO degradation of NOM by this catalytic system were employed [17,31]: $475 \mathrm{~cm}^{3}$ of synthetic NOM or phenol solution and $3.81 \mathrm{~g} / \mathrm{dm}^{3}$ of the powdered clay catalyst (Al/Fe-PILC, 60-mesh) were poured in the photoreactor under constant stirring and air bubbling through $30 \mathrm{~min}$ of previous equilibrium between the solid catalyst and the NOM or phenol solution $\left(7.0 \mathrm{mg} \mathrm{C} / \mathrm{dm}^{3}\right)$. Then both, lamp irradiation (either visible or UV) and addition of $\mathrm{H}_{2} \mathrm{O}_{2}$ solution $\left(100 \mathrm{~cm}^{3}\right)$ were started at the same time. The peroxide solution was added during $3.0 \mathrm{~h}$ in a proper concentration to provide a dose of $3.77 \mathrm{mg} \mathrm{H} \mathrm{H}_{2} \mathrm{O}_{2} / \mathrm{mg}$ DOC under a constant flow rate $\left(0.56 \mathrm{~cm}^{3} / \mathrm{min}\right)$. The system was then kept under UV or Vis irradiation by additional $30 \mathrm{~min}$ to enhance hydrogen peroxide utilization by the photocatalytic system. Sampling was made throughout $4 \mathrm{~h}$ for every experiment. Control experiments were also performed under following conditions: (i) CWPO-natural light under natural lab's lighting without extra UV or vis radiation; (ii) CWPO-dark, where the reactor was covered with an aluminum foil; (iii) CWPO-without air and natural lighting where nitrogen was bubbled instead of air to evidence the effect of dissolved oxygen on the photocatalytic performance; (iv) UV-NOM to check effect of the UV irradiation without any addition of catalyst or peroxide; (v) UV$\mathrm{Al} / \mathrm{Fe}-\mathrm{PILC}$ to determine possible contributions of both adsorption of NOM on the catalyst surface and the purely photocatalytic degradation under UV light without addition of hydrogen peroxide; (vi) $\mathrm{UV}-\mathrm{H}_{2} \mathrm{O}_{2}$ to determine the simultaneous effect of the oxidizing agent and the UV irradiation without the presence of the solid catalyst; (vii) UV-Fe to establish the potential contribution of homogeneous photo-Fenton under UV light, in the presence of a dissolved iron salt $\left(\mathrm{FeSO}_{4}\right)$ in the same amount of active iron present in the solid catalyst $\left(65 \mathrm{mg} \mathrm{Fe}^{2+} / \mathrm{dm}^{3}\right)$. All control experiments made under UV-irradiation were also made under Vis-irradiation. Finally, a further photocatalytic test was performed in the presence of the starting mineral and either UV or visible light to rule out the effect of structural iron naturally occurring in the starting unmodified clay.

\subsection{Analytic Methods}

The $25 \mathrm{~cm}^{3}$ samples collected at every time of reaction through the catalytic tests were immediately microfiltered after taken (Millipore PVDF, $0.45 \mu \mathrm{m}$ ) to determine true color at $456 \mathrm{~nm}$ (Standard Method 2120-C [64]) in a 6850 UV/Vis spectrophotometer, JENWAY. In the case of the experiments of phenol degradation, it was measured in a Varian Pro Star HPLC equipment with a 250/4.5 Nucleodur C18 HTec, $5 \mu \mathrm{m}$ (Macherey Nagel) column thermostated at $40{ }^{\circ} \mathrm{C}$. The mobile phase $\left(0.2 \mathrm{MeOH}: 0.8 \mathrm{H}_{3} \mathrm{PO}_{4}, 1.0 \times 10^{-3} \mathrm{~mol} / \mathrm{dm}^{3}\right)$, was used at a flow rate of $1.0 \mathrm{~cm}^{3} / \mathrm{min}$, where the diode array detector was set at $210 \mathrm{~nm}$. The dissolved organic carbon (DOC) was measured by the technique of non-purgeable organic compounds (NPOC) in a TOC-V CPH Shimadzu analyzer, and its elimination hereafter referred to as DOC mineralization. The concentration of $\mathrm{H}_{2} \mathrm{O}_{2}$ was determined by the iodometric method [65] and used to calculate the $\mathrm{H}_{2} \mathrm{O}_{2}$ consumption. 


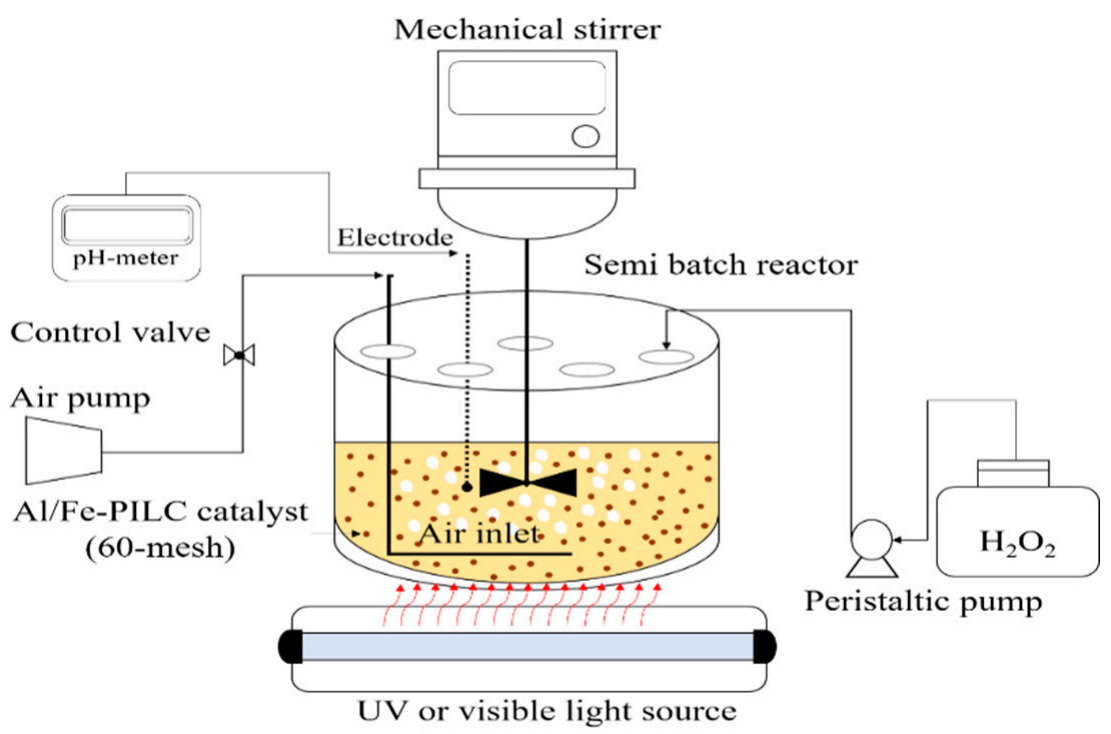

Figure 7. Experimental setup used in the CWPO photocatalytic tests for NOM/phenol degradation. PLL18W Philips lamp provided UV irradiation $(\lambda: 365 \mathrm{~nm})$, irradiance power of $6 \mathrm{~mW} / \mathrm{cm}^{2}$; LED lamp (with a small fan for temperature control) provided visible irradiation (steepest wavelength at 450 and $550 \mathrm{~nm}$ ), irradiation power $160 \mathrm{~mW} / \mathrm{cm}^{2}$.

\section{Conclusions}

$\mathrm{An} \mathrm{Al} / \mathrm{Fe}-\mathrm{PILC}$ clay catalyst was prepared from low cost technical grade reagents; the catalyst exhibited physicochemical properties characteristic of successfully pillared clays, in terms of both basal spacing $(1.67 \mathrm{~nm})$ and specific BET surface $\left(153 \mathrm{~m}^{2} / \mathrm{g}\right)$, whereas incorporated $1.72 \% w / w$ Fe. The visible-light irradiation (LED lamp, 450 and $550 \mathrm{~nm}$ peaks) showed to significantly enhance all DOC mineralization (72\%), color removal (73\%) and $\mathrm{H}_{2} \mathrm{O}_{2}$ consumption of a synthetic surrogate of dissolved natural organic matter at neutral $\mathrm{pH}$ in comparison to either dark conditions or UV-irradiation $(\lambda: 365 \mathrm{~nm})$. Such an enhanced Photo-CWPO degradation of NOM seems to be supported in the synergistically coupling of ${ }^{3} \mathrm{NOM}^{*}$ states to the improved reduction of surface $\mathrm{Fe}^{3+}$ into $\mathrm{Fe}^{2+}$, the well-known rate-determining step of the Fenton process. Several control experiments demonstrated that neither, straight $\mathrm{H}_{2} \mathrm{O}_{2}$ or NOM photolysis, heterogeneous photo-Fenton, adsorption, framework iron occurring in the starting clay mineral or homogeneous Fenton driven by the tiny concentrations of leached $\mathrm{Fe}$ can successfully explain the outstanding catalytic performance exhibited by the NOM-Al/Fe-PILC- $\mathrm{H}_{2} \mathrm{O}_{2}$ system assisted by visible light at ambient conditions of temperature and pressure. Furthermore, very low DOC mineralization of phenol (using same DOC loading) in absence of NOM was recorded, strongly disregarding the heterogeneous photo-Fenton effect to significantly explain the observed enhanced degradation of NOM. Furthermore, under visible light quite similar photo-catalytic efficiencies were achieved at both $\mathrm{pH} 7.0$ and 3.0, what should really facilitate the application of the photo-CWPO process to enhance conventional drinking water treatment plants.

Author Contributions: Conceptualization, C.G. and L.A.G.; methodology, A.M.G.-M., F.D. and C.S.P.-D.; formal analysis, A.M.G.-M. and L.A.G.; investigation, A.M.G.-M. and C.S.P.-D.; resources, A.M.G.-M. and F.D.; data curation, A.M.G.-M. and F.D.; writing-original draft preparation, C.S.P.-D. and A.M.G.-M.; writing-review and editing, C.G. and L.A.G.; project administration, C.G. and L.A.G.; funding acquisition, C.G. and L.A.G. All authors have read and agreed to the published version of the manuscript.

Funding: Financial support from Drinking Water Nariño SGR project (BPIN 2014000100020), Institut de Recherches sur la Catalyse et l'Environnement de Lyon (IRCELYON) and Centro de Estudios Ambientales (CEA), Facultad de Ciencias, Universidad de Nariño (Agreement 149, 2019) is kindly appreciated. 
Acknowledgments: Administrative and technical support by Catherine Pinel—chief of the Institut de Recherches sur la Catalyse et l'Environnement de Lyon (IRCELYON) and Arsenio Hidalgo-Head of Centro de Asesorías en Estadística (CEASE)-Universidad de Nariño is thankfully acknowledged.

Conflicts of Interest: The authors declare no conflict of interest. The funders had no role in the design of the study; in the collection, analyses or interpretation of data; in the writing, of the manuscript or in the decision to publish the results.

\section{References}

1. Sorlini, S. Natural Organic Matter: Characterization and Removal by AOPs to Assist Drinking Water Facilities. In Applications of Advanced Oxidation Processes (AOPs) in Drinking Water Treatment, 1st ed.; Gil, A., Galeano, L.A., Vicente, M.A., Eds.; Springer International Publishing: Cham, Switzerland, 2019; Volume 67, pp. 53-68. [CrossRef]

2. Valencia, S.; Marín, J.; Restrepo, G. Photocatalytic Degradation of Humic Acids with Titanium Dioxide Embedded into Polyethylene Pellets to Enhance the Postrecovery of Catalyst. Environ. Eng. Sci. 2017, 35, 185-193. [CrossRef]

3. Deng, Y.; Zhao, R. Advanced Oxidation Processes (AOPs) in Wastewater Treatment. Curr. Pollut. Rep. 2015, 1, 167-176. [CrossRef]

4. Thomas, N.; Dionysiou, D.D.; Pillai, S.C. Heterogeneous Fenton catalysts: A review of recent advances. J. Hazard. Mater. 2021, 404, 124082. [CrossRef]

5. Chong, M.N.; Jin, B.; Chow, C.W.K.; Saint, C. Recent developments in photocatalytic water treatment technology: A review. Water Res. 2010, 44, 2997-3027. [CrossRef]

6. Li, T.; Zhang, C.-Z.; Fan, X.; Li, Y.; Song, M. Degradation of oxidized multi-walled carbon nanotubes in water via photo-Fenton method and its degradation mechanism. Chem. Eng. J. 2017, 323, 37-46. [CrossRef]

7. Vilhunen, S.H.; Sillanpää, M.E.T. Ultraviolet light emitting diodes and hydrogen peroxide in the photodegradation of aqueous phenol. J. Hazard. Mater. 2009, 161, 1530-1534. [CrossRef] [PubMed]

8. Sillanpää, M.; Ncibi, M.C.; Matilainen, A. Advanced oxidation processes for the removal of natural organic matter from drinking water sources: A comprehensive review. J. Environ. Manage. 2018, 208, 56-76. [CrossRef] [PubMed]

9. Martínez, F.; Calleja, G.; Melero, J.A.; Molina, R. Iron species incorporated over different silica supports for the heterogeneous photo-Fenton oxidation of phenol. Appl. Catal. B Environ. 2007, 70, 452-460. [CrossRef]

10. González-Bahamón, L.F.; Hoyos, D.F.; Benítez, N.; Pulgarín, C. New Fe-immobilized natural bentonite plate used as photo-Fenton catalyst for organic pollutant degradation. Chemosphere 2011, 82, 1185-1189. [CrossRef]

11. Lu, M.; Wang, J.; Wang, Y.; He, Z. Heterogeneous Photo-Fenton Catalytic Degradation of Practical Pharmaceutical Wastewater by Modified Attapulgite Supported Multi-Metal Oxides. Water 2021, 13, 156. [CrossRef]

12. Truong, H.B.; Huy, B.T.; Ray, S.K.; Lee, Y.-I.; Cho, J.; Hur, J. $\mathrm{H}_{2} \mathrm{O}_{2}$-assisted photocatalysis for removal of natural organic matter using nanosheet $\mathrm{C}_{3} \mathrm{~N}_{4}-\mathrm{WO}_{3}$ composite under visible light and the hybrid system with ultrafiltration. Chem. Eng. J. 2020, 399, 125733. [CrossRef]

13. Gil, A. Materiales porosos basados en arcillas pilareadas: Control de su estructura para aplicaciones medioambientales y energéticas. Av. Cienc. Ing. 2012, 3, 137-148.

14. Muñoz, H.-J.; Vallejo, C.; Blanco, C.; Gil, A.; Vicente, M.-Á.; Ramírez, J.-H.; Galeano, L.-A. 10 kg scaled-up preparation of $\mathrm{Al} / \mathrm{Fe}$-pillared clay CWPO catalysts from concentrated precursors. Green Chem. 2018, 20, 5196-5208. [CrossRef]

15. Vallejo, C.A.; Galeano, L.A.; Trujillano, R.; Vicente, M.Á.; Gil, A. Preparation of Al/Fe-PILC clay catalysts from concentrated precursors: Enhanced hydrolysis of pillaring metals and intercalation. RSC Adv. 2020, 10, 40450-40460. [CrossRef]

16. Ramírez, J.H.; Galeano, L.A.; Pinchao, G.; Bedoya, R.A.; Hidalgo, A. Optimized CWPO phenol oxidation in CSTR reactor catalyzed by Al/Fe-PILC from concentrated precursors at circumneutral pH. J. Environ. Chem. Eng. 2018, 6, 2429-2441. [CrossRef]

17. Garcia-Mora, A.M.; Torres-Palma, R.A.; García, H.; Hidalgo-Troya, A.; Galeano, L.-A. Removal of dissolved natural organic matter by the $\mathrm{Al} / \mathrm{Fe}$ pillared clay-activated-catalytic wet peroxide oxidation: Statistical multi-response optimization. J. Water Process Eng. 2021, 39, 101755. [CrossRef]

18. Ordoñez-Ordoñez, A.; Revelo-Romo, D.M.; Garcia-Mora, A.M.; Hidalgo-Troya, A.; Galeano, L.-A. MS2 coliphage inactivation by Al/Fe PILC-activated Catalytic Wet Peroxide Oxidation: Multiresponse statistical optimization. Heliyon 2019, 5, e01892. [CrossRef]

19. Khankhasaeva, S.T.; Badmaeva, S.V. Removal of p-aminobenzenesulfanilamide from water solutions by catalytic photo-oxidation over Fe-pillared clay. Water Res. 2020, 185, 116212. [CrossRef] [PubMed]

20. Truong, H.B.; Huy, B.T.; Ly, Q.V.; Lee, Y.-I.; Hur, J. Visible light-activated degradation of natural organic matter (NOM) using zinc-bismuth oxides-graphitic carbon nitride (ZBO-CN) photocatalyst: Mechanistic insights from EEM-PARAFAC. Chemosphere 2019, 224, 597-606. [CrossRef] [PubMed]

21. Wang, S.-Q.; Li, J.-M.; Liu, W.-B. Effect of F, V and Mn co-doping on the catalytic performance of $\mathrm{TiO}_{2}$-pillared bentonite in the photocatalytic denitration. J. Fuel Chem. Technol. 2020, 48, 1131-1139. [CrossRef]

22. Hadjltaief, H.B.; Zina, M.B.; Galvez, M.E.; Da Costa, P. Photo-Fenton oxidation of phenol over a Cu-doped Fe-pillared clay. C. R. Chim. 2015, 18, 1161-1169. [CrossRef]

23. Guimarães, V.; Teixeira, A.R.; Lucas, M.S.; Silva, A.M.T.; Peres, J.A. Pillared interlayered natural clays as heterogeneous photocatalysts for $\mathrm{H}_{2} \mathrm{O}_{2}$-assisted treatment of a winery wastewater. Sep. Purif. Technol. 2019, 228, 115768. [CrossRef] 
24. Parker, K.M.; Pignatello, J.J.; Mitch, W.A. Influence of Ionic Strength on Triplet-State Natural Organic Matter Loss by Energy Transfer and Electron Transfer Pathways. Environ. Sci. Technol. 2013, 47, 10987-10994. [CrossRef]

25. Richard, C.; Canonica, S. Aquatic Phototransformation of Organic Contaminants Induced by Coloured Dissolved Natural Organic Matter. In Environmental Photochemistry Part II; Boule, P., Bahnemann, D.W., Robertson, P.K.J., Eds.; Springer: Berlin/Heidelberg, Germany, 2005; pp. 299-323.

26. Li, Y.; Pan, Y.; Lian, L.; Yan, S.; Song, W.; Yang, X. Photosensitized degradation of acetaminophen in natural organic matter solutions: The role of triplet states and oxygen. Water Res. 2017, 109, 266-273. [CrossRef]

27. Muñoz, H.-J.; Blanco, C.; Gil, A.; Vicente, M.-Á.; Galeano, L.-A. Preparation of Al/Fe-Pillared Clays: Effect of the Starting Mineral. Materials 2017, 10, 1364. [CrossRef] [PubMed]

28. Kooli, F. Pillared montmorillontes from unusual antiperspirant aqueous solutions: Characterization and catalytic tests. Microporous Mesoporous Mater. 2013, 167, 228-236. [CrossRef]

29. Thommes, M.; Kaneko, K.; Neimark, A.V.; Olivier, J.P.; Rodriguez-Reinoso, F.; Rouquerol, J.; Sing, K.S.W. Physisorption of gases, with special reference to the evaluation of surface area and pore size distribution (IUPAC Technical Report). Pure Appl. Chem. 2015, 87, 9-10. [CrossRef]

30. Galeano, L.-A.; Vicente, M.Á.; Gil, A. Catalytic Degradation of Organic Pollutants in Aqueous Streams by Mixed Al/M-Pillared Clays (M = Fe, Cu, Mn). Catal. Rev. 2014, 56, 239-287. [CrossRef]

31. García Mora, A.M.; Portilla Delgado, C.S.; Torres Palma, R.A.; Hidalgo Troya, A.; Galeano, L.A. Catalytic wet peroxide oxidation of natural organic matter to enhance the treatment of real surface water at urban and rural drinking water plants. J. Water Process Eng. 2021. accepted.

32. Rezaee, R.; Maleki, A.; Jafari, A.; Mazloomi, S.; Zandsalimi, Y.; Mahvi, A.H. Application of response surface methodology for optimization of natural organic matter degradation by $\mathrm{UV} / \mathrm{H}_{2} \mathrm{O}_{2}$ advanced oxidation process. J. Environ. Health Sci. Eng. 2014, 12, 67. [CrossRef]

33. Santos-Juanes, L.; Sánchez, J.L.G.; López, J.L.C.; Oller, I.; Malato, S.; Sánchez Pérez, J.A. Dissolved oxygen concentration: A key parameter in monitoring the photo-Fenton process. Appl. Catal. B Environ. 2011, 104, 316-323. [CrossRef]

34. Jung, H.-J.; Hong, J.-S.; Suh, J.-K. A comparison of fenton oxidation and photocatalyst reaction efficiency for humic acid degradation. J. Ind. Eng. Chem. 2013, 19, 1325-1330. [CrossRef]

35. O'Dowd, K.; Pillai, S.C. Photo-Fenton disinfection at near neutral pH: Process, parameter optimization and recent advances. J. Environ. Chem. Eng. 2020, 8, 104063. [CrossRef]

36. Sarathy, S.; Mohseni, M. The fate of natural organic matter during $\mathrm{UV} / \mathrm{H}_{2} \mathrm{O}_{2}$ advanced oxidation of drinking water. Can. J. Civ. Eng. 2008, 36, 160-169. [CrossRef]

37. Cheng, M.; Song, W.; Ma, W.; Chen, C.; Zhao, J.; Lin, J.; Zhu, H. Catalytic activity of iron species in layered clays for photodegradation of organic dyes under visible irradiation. Appl. Catal. B Environ. 2008, 77, 355-363. [CrossRef]

38. De León, M.A.; Castiglioni, J.; Bussi, J.; Sergio, M. Catalytic activity of an iron-pillared montmorillonitic clay mineral in heterogeneous photo-Fenton process. Catal. Today 2008, 133-135, 600-605. [CrossRef]

39. Lei, X.; Pan, J.; Devlin, A.T. Characteristics of Absorption Spectra of Chromophoric Dissolved Organic Matter in the Pearl River Estuary in Spring. Remote Sens. 2019, 11, 1533. [CrossRef]

40. Wenk, J.; von Gunten, U.; Canonica, S. Effect of Dissolved Organic Matter on the Transformation of Contaminants Induced by Excited Triplet States and the Hydroxyl Radical. Environ. Sci. Technol. 2011, 45, 1334-1340. [CrossRef]

41. Page, S.E.; Arnold, W.A.; McNeill, K. Assessing the Contribution of Free Hydroxyl Radical in Organic Matter-Sensitized Photohydroxylation Reactions. Environ. Sci. Technol. 2011, 45, 2818-2825. [CrossRef] [PubMed]

42. Guo, S.; Yang, W.; You, L.; Li, J.; Chen, J.; Zhou, K. Simultaneous reduction of Cr (VI) and degradation of tetracycline hydrochloride by a novel iron-modified rectorite composite through heterogeneous photo-Fenton processes. Chem. Eng. J. 2020, $393,124758$. [CrossRef]

43. Xu, H.; Cooper, W.J.; Jung, J.; Song, W. Photosensitized degradation of amoxicillin in natural organic matter isolate solutions. Water Res. 2011, 45, 632-638. [CrossRef] [PubMed]

44. O'Connor, M.; Helal, S.R.; Latch, D.E.; Arnold, W.A. Quantifying photo-production of triplet excited states and singlet oxygen from effluent organic matter. Water Res. 2019, 156, 23-33. [CrossRef] [PubMed]

45. Canonica, S. Oxidation of Aquatic Organic Contaminants Induced by Excited Triplet States. CHIMIA Int. J. Chem. 2007, 61, 641-644. [CrossRef]

46. Sels, B.F.; De Vos, D.E.; Jacobs, P.A. Kinetics of the Oxygenation of Unsaturated Organics with Singlet Oxygen Generated from $\mathrm{H}_{2} \mathrm{O}_{2}$ by a Heterogeneous Molybdenum Catalyst. J. Am. Chem. Soc. 2007, 129, 6916-6926. [CrossRef] [PubMed]

47. Zhang, D.; Yan, S.; Song, W. Photochemically Induced Formation of Reactive Oxygen Species (ROS) from Effluent Organic Matter. Environ. Sci. Technol. 2014, 48, 12645-12653. [CrossRef]

48. Sun, L.; Qian, J.; Blough, N.V.; Mopper, K. Insights into the Photoproduction Sites of Hydroxyl Radicals by Dissolved Organic Matter in Natural Waters. Environ. Sci. Technol. Lett. 2015, 2, 352-356. [CrossRef]

49. Bodhipaksha, L.C.; Sharpless, C.M.; Chin, Y.-P.; Sander, M.; Langston, W.K.; MacKay, A.A. Triplet Photochemistry of Effluent and Natural Organic Matter in Whole Water and Isolates from Effluent-Receiving Rivers. Environ. Sci. Technol. 2015, 49, 3453-3463. [CrossRef] [PubMed] 
50. Zhan, M.; Yang, X.; Xian, Q.; Kong, L. Photosensitized degradation of bisphenol A involving reactive oxygen species in the presence of humic substances. Chemosphere 2006, 63, 378-386. [CrossRef]

51. Garg, S.; Rose, A.L.; Waite, T.D. Photochemical production of superoxide and hydrogen peroxide from natural organic matter. Geochim. Cosmochim. Acta 2011, 75, 4310-4320. [CrossRef]

52. Merino, C.; Kuzyakov, Y.; Godoy, K.; Jofré, I.; Nájera, F.; Matus, F. Iron-reducing bacteria decompose lignin by electron transfer from soil organic matter. Sci. Total Environ. 2021, 761, 143194. [CrossRef]

53. Poggenburg, C.; Mikutta, R.; Schippers, A.; Dohrmann, R.; Guggenberger, G. Impact of natural organic matter coatings on the microbial reduction of iron oxides. Geochim. Cosmochim. Acta 2018, 224, 223-248. [CrossRef]

54. Orsetti, S.; Laskov, C.; Haderlein, S.B. Electron Transfer between Iron Minerals and Quinones: Estimating the Reduction Potential of the Fe (II)-Goethite Surface from AQDS Speciation. Environ. Sci. Technol. 2013, 47, 14161-14168. [CrossRef]

55. Golanoski, K.S.; Fang, S.; Del Vecchio, R.; Blough, N.V. Investigating the Mechanism of Phenol Photooxidation by Humic Substances. Environ. Sci. Technol. 2012, 46, 3912-3920. [CrossRef]

56. Bauer, I.; Kappler, A. Rates and Extent of Reduction of Fe (III) Compounds and $\mathrm{O}_{2}$ by Humic Substances. Environ. Sci. Technol. 2009, 43, 4902-4908. [CrossRef]

57. Elsner, M.; Schwarzenbach, R.P.; Haderlein, S.B. Reactivity of Fe (II)-Bearing Minerals toward Reductive Transformation of Organic Contaminants. Environ. Sci. Technol. 2004, 38, 799-807. [CrossRef] [PubMed]

58. Xiao, Y.; Carena, L.; Näsi, M.-T.; Vähätalo, A.V. Superoxide-driven autocatalytic dark production of hydroxyl radicals in the presence of complexes of natural dissolved organic matter and iron. Water Res. 2020, 177, 115782. [CrossRef] [PubMed]

59. Bai, Y.; Subdiaga, E.; Haderlein, S.B.; Knicker, H.; Kappler, A. High-pH and anoxic conditions during soil organic matter extraction increases its electron-exchange capacity and ability to stimulate microbial Fe (III) reduction by electron shuttling. Biogeosciences 2020, 17, 683-698. [CrossRef]

60. Sundman, A.; Byrne, J.M.; Bauer, I.; Menguy, N.; Kappler, A. Interactions between magnetite and humic substances: Redox reactions and dissolution processes. Geochem. Trans. 2017, 18, 6. [CrossRef]

61. Pignatello, J.J.; Oliveros, E.; MacKay, A. Advanced oxidation processes for organic contaminant destruction based on the Fenton reaction and related chemistry. Crit. Rev. Environ. Sci. Technol. 2006, 36, 1-84. [CrossRef]

62. Clarizia, L.; Russo, D.; Di Somma, I.; Marotta, R.; Andreozzi, R. Homogeneous photo-Fenton processes at near neutral pH: A review. Appl. Catal. B Environ. 2017, 209, 358-371. [CrossRef]

63. Wang, H.; Zhu, Y.; Hu, C. Impacts of bacteria and corrosion on removal of natural organic matter and disinfection byproducts in different drinking water distribution systems. Int. Biodeterior. Biodegrad. 2017, 117, 52-59. [CrossRef]

64. Baird, R.B. Standard Methods for the Examination of Water and Wastewater, 23rd ed.; American Public Health Association (APHA): Washington, DC, USA; American Water Works Association (AWWA): Denver, CO, USA; Water Environment Federation (WEF): Alexandria, VA, USA, 2017.

65. Kiassen, N.; Marchington, D.; McGowant, H. $\mathrm{H}_{2} \mathrm{O}_{2}$ Determination by the Is- Method and by $\mathrm{KMnO}_{4}$ Titration. Anal. Chem. 1994, 66, 2921-2925. [CrossRef] 